Widya Sari

\title{
PRODUKSI, DISTRIBUSI, DAN KONSUMSI DALAM ISLAM
}

\begin{abstract}
Abstrak
Pola konsumsi dan perilaku produksi menentukan roda perekonomian. AlQur'an sebagai sumber ajaran, memiliki ajaran tentang konsumsi, produksi dan distribusi disamping aktivitas-aktivitas perekonomian lainnya. Dalam konteks produksi, tentu saja produsen muslim sama sekali sebaiknya tidak tergoda oleh kebiasaan dan perilaku ekonom-ekonomi yang bersifat menjalankan dosa, memakan harta terlarang, menyebarkan permusuhan, berlawanan dengan sunnatullah, dan menimbulkan kerusakan di muka bumi. Walau bagaimanapun, secanggih alat untuk menghitung nikmat Allah pasti tidak akan menghitungnya.

Dalam konseptual konsumsi ada beberapa prinsip yang harus dipatuhi oleh konsumen muslim, yang antara lain : prinsip halal dan baik, prinsip ketiadaan mengikuti hawa nafsu, prinsip sukur.

Sistem ekonomi Islam menawarkan sistem penditribusian ekonomi yang mengedepankan nilai kebebasan dalam bertindak dan berbuat dengan dilandasi oleh ajaran agama serta nilai keadilan dalam kepemilikan yang disandarkan pada dua sendi, yaitu kebebasan dan keadilan.
\end{abstract}

Kata Kunci: Islam, produksi, distribusi, konsumsi.

\section{Pendahuluan}

Islam sebagai system hidup (way of life) dan merupakan agama yang universal sebab memuat segala aspek kehidupan baik yang terkait dengan aspek ekonomi, sosial, politik dan budaya. Seiring dengan maju pesatnya kajian tentang ekonomi Islam dengan menggunakan pendekatan filsafat dan sebagainya mendorong kepada terbentuknya suatu ilmu ekonomi berbasis keIslaman yang terfokus untuk mempelajari masalah-masalah, ekonomi, rakyat, yang dilhami oleh nilai-nilai Islam.

Adapun bidang kajian yang terpenting dalam perekonomian adalah bidang Produksi, Distribusi dan Konsumsi. Distribusi misalnya, menjadi posisi penting dari teori ekonomi mikro baik dalam system ekonomi Islam maupun kapitalis sebab pembahasan dalam bidang distribusi ini tidak hanya berkaitan dengan aspek ekonomi belaka tetapi juga aspek social dan politik sehingga menjadi perhatian bagi aliran pemikir ekonomi Islam dan konvensional sampai saat,ini.

Pada saat ini realita yang nampak adalah telah terjadi ketidakadilan dan ketimpangan dalam pendistribusian pendapatan dan kekayaan baik di negara maju maupun di negara-negara berkembang yang mempergunakan system kapitalis sebagai system ekonomi negaranya, sehingga menciptakan kemiskinan dimana-mana. 
Menanggapi kenyataan tersebut Islam sebagai agama yang universal diharapkan dapat menyelesaikan permasalahan tersebut dan sekaligus menjadi sistem perekonomian suatu negara.

Dari permasalahan di atas kami ingin membahas tentang produksi, distribusi dan konsumsi dengan melihat perspektif Islam dengan melalui hadits-hadit Rasullulah sebagai pendukung, oleh karena itu kami sepakat memberikan judul makalah ini yaitu:"Produksi, Distribusi dan Konsumsi dalam Ekonomi Islam".

\section{Produksi dan Permasalahannya}

\section{A. Pengertian}

Dalam ekonomi Islam, produksi mempunyai motif kemaslatan, kebutuhan dan kewajiban. Demikian pula, konsumsi. Perilaku produksi merupakan usaha seseorang atau kelompok untuk melepaskan dirinya dari kefakiran. Menurut Yusuf Qardhawi (1995), secara eksternal perilaku produksi dimaksudkan untuk memenuhi kebutuhan setiap individu sehingga dapat membangun kemandirian ummat. Sedangkan motif perilakunya adalah keutamaan mencari nafkah, menjaga semua sumber daya (flora-fauna dan alam sekitar), dilakukan secara profesional dan berusaha pada sesuatu yang halal. Karena itu dalam sebuah perusahaan misalnya, menurut M.M. Metwally ${ }^{1}$ asumsi-asumsi produksi, harus dilakukan untuk barang halal dengan proses produksi dan pasca produksi yang tidak menimbulkan ke-madharatan. Semua orang diberikan kebebasan untuk melakukan usaha produksi.

Berdasarkan pertimbangan kemashlahatan itulah, menurut Muhammad Abdul Mannan ${ }^{2}$, pertimbangan perilaku produksi tidak semata-mata didasarkan pada permintaan pasar.

Produksi dalam ekonomi Islam adalah setiap bentuk aktivitas yang dilakukan manusia untuk mewujudkan manfaat atau menambahkannya dengan cara mengeksplorasi sumber-sumber ekonomi yang disediakan Allah SWT sehingga menjadi maslahat, untuk memenuhi kebutuhan manusia. ${ }^{3} \mathrm{Hal}$ ini dapat dijelaskan dalam semua aktifitas produksi barang dan jasa yang dilakukan seorang muslim untuk memperbaiki apa yang dimilikinya, baik berupa sumber daya alam dan harta dan dipersiapkan untuk bisa dimanfaatkan oleh pelakunya atau oleh umat Islam. Firman Allah dalam QS Al-Mulk:15

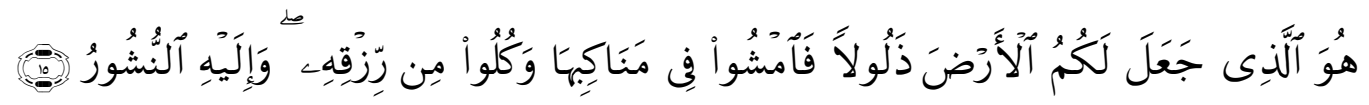

"Dialah yang menjadikan bumi itu mudah bagi kamu, Maka berjalanlah di segala penjurunya dan makanlah sebahagian dari rezki-Nya. dan hanya kepadaNya-lah kamu (kembali setelah) dibangkitkan." 
Dan firman-Nya pula dalam QS Hud:61

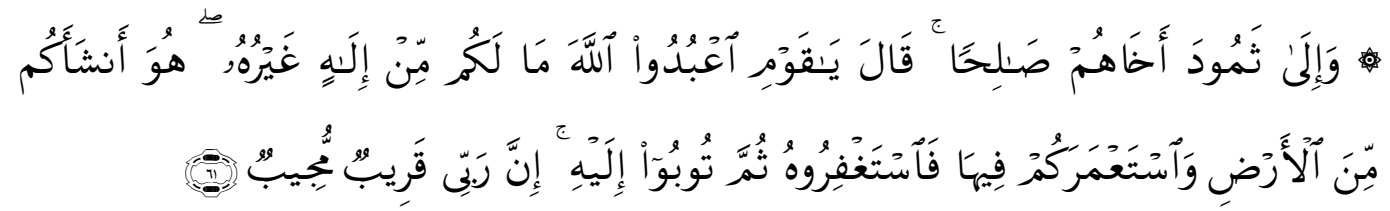

"Dan kepada Tsamud (kami utus) saudara mereka shaleh. Shaleh berkata: "Hai kaumku, sembahlah Allah, sekali-kali tidak ada bagimu Tuhan selain Dia. Dia telah menciptakan kamu dari bumi (tanah) dan menjadikan kamu pemakmurnya, karena itu mohonlah ampunan-Nya, kemudian bertobatlah kepada-Nya, Sesungguhnya Tuhanku Amat dekat (rahmat-Nya) lagi memperkenankan (doa hamba-Nya)."

\section{B. Prinsip-prinsip Produksi}

Prinsip-prinsp produksi secara singkat adalah pedoman yang harus diperhatikan, ditaati, dan dilakukan ketika akan berproduksi. Prinsip-prinsip produksi dalam Islam, diantaranya adalah sebagai berikut:

\section{Berproduksi dalam lingkaran halal}

Prinsip produksi yang wajib dilaksanakan oleh setiap muslim, baik individu maupun komunitas adalah berpegang pada semua yang dihalalkan Allah dan tidak melewati batas. Pada dasarnya, produsen pada ekonomi konvensional tidak mengenal istilah halal dan haram. Yang menjadi prioritas kerja mereka adalah memenuhi keinginan pribadi dengan mengumpulkan laba, harta, dan uang. Ia tidak mementingkan apakah yang diproduksinya itu bermanfaat atau berbahaya, baik atau buruk, etis atau tidak etis. Adapun sikap seorang muslim sangat bertolak belakang. Ia tidak boleh menanam apa-apa yang diharamkan. Seorang muslim tidak boleh menanam segala jenis tumbuhan yang membahayakan manusia, seperti tembakau yang menurut keterangan WHO, sains, dan hasil riset berbahaya bagi manusia. Selain dilarang menanam tanaman-tanaman yang berbahaya bagi manusia, sorang muslim juga dilarang memproduksi barang-barang haram, baik haram dikenakan maupun haram dikoleksi. Misalnya membuat patung atau cawan dari bahan emas dan perak, dan membuat gelang emas untuk laki-laki. Syariat juga melarang memproduksi produk yang merusak akidah, etika, dan moral manusia, seperti produk yang berhubungan dengan pornografi dan sadisme, baik dalam opera, film, dan musik. ${ }^{4}$

2. Keadilan dalam berproduksi

Sistem ekonomi Islam telah memberikan keadilan dan persamaan prinsip produksi sesuai kemampuan masing-masing tanpa menindas orang lain atau menghancurkan masyarakat. Kitab suci Al-Quran memperbolehkan 
kerjasama yang saling menguntungkan dengan jujur, sederajat, dan memberikan keuntungan bagi kedua pihak dan tidak membenarkan cara-cara yang hanya menguntungkan seseorang, lebih-lebih yang dapat mendatangkan kerugian pada orang lain atau keuntungan yang diperoleh ternyata merugikan kepentingan umum. Setiap orang dinasihatkan berhubungan secara jujur dan teratur serta menahan diri dari hubungan yang tidak jujur sebagaimana tersebut dalam QS An Nisa': 29

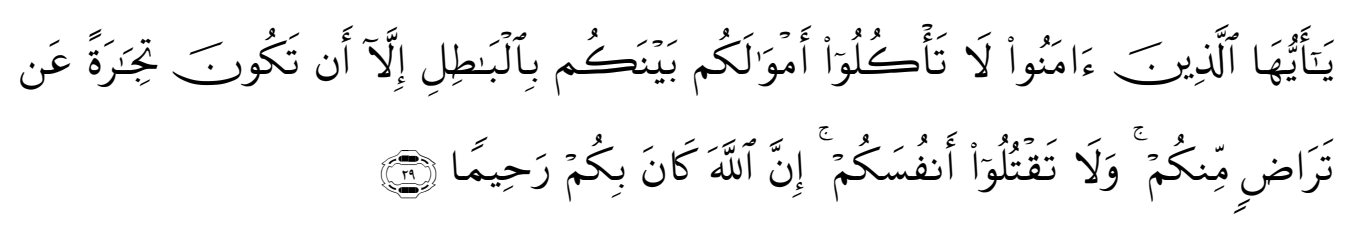

Hai orang-orang yang beriman, janganlah kamu saling memakan harta sesamamu dengan jalan yang batil, kecuali dengan jalan perniagaan yang Berlaku dengan suka sama-suka di antara kamu. dan janganlah kamu membunuh dirimu, ${ }^{5}$ Sesungguhnya Allah adalah Maha Penyayang kepadamu.

Ayat di atas melarang cara mendapatkan kekayaan dengan cara yang tidak adil dan memperingatkan akan akibat buruk yang ditimbulkan oleh perbuatan-perbuatan yang tidak adil. Jika seseorang mencari dan mendapatkan kekayaan dengan cara yang tidak benar ia tidak hanya merusak usaha dirinya, tetapi akan menciptakan kondisi yang tidak harmonis di pasar yang pada akhirnya akan menghancurkan usaha orang lain. ${ }^{6}$ Selain itu dalam QS Ar Rahman

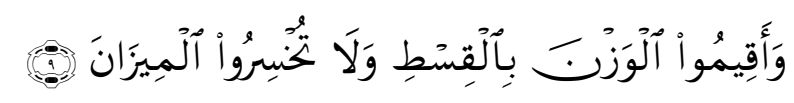

"Dan Tegakkanlah timbangan itu dengan adil dan janganlah kamu mengurangi neraca itu."

Ayat di atas menjelaskan bahwa tiap orang Islam hendaknya jujur dalam setiap tindakan, sebagaimana timbangan yang tepat ketika berjualan dan dalam semua kegiatan yang berkenaan dengan orang lain. Orang Islam tidak boleh tertipu daya karena contoh kualitas yang baik, lalu menjual barang-barang yang rendah mutunya atau mengurangi timbangan. ${ }^{7}$ Karena pada dasarnya perbuatan tidak adil dan salah akan merusak sistem ekonomi dan akhirnya akan menghancurkan keseluruhan system sosial. Dengan demikian, Al Quran menyetujui nilai-nilai yang mulia dalam persamaan hak, keadilan, kooperasi, dan pengorbanan dalam rangka mereorganisasikan lingkungan sosio-ekonomi masyarakat Islam. 
3. Seluruh kegiatan produksi terikat pada tataran nilai moral dan teknikal yang Islami. ${ }^{8}$

Sejak dari kegiatan mengorganisisr faktor produksi, proses produksi hingga pemasaran dan pelayanan kepada konsumen semuanya harus mengikuti moralitas Islam. Metwally (1992) mengatakan "perbedaan dari perusahaan-perusahaan non Islami tak hanya pada tujuannya, tetapi juga pada kebijakan-kebijakan ekonomi dan strategi pasarnya". Produksi barang dan jasa yang dapat merusak moralitas dan menjauhkan manusia dari nilai-nilai relijius tidak akan diperbolehkan. Selain itu Islam juga mengajarkan adanya skala prioritas (dharuriyah, hajjiyah dan tahsiniyah) dalam pemenuhan kebutuhan konsumsi serta melarang sikap berlebihan, larangan ini juga berlaku bagi segala mata rantai dalam produksinya.

4. Kegiatan produksi harus memperhatikan aspek sosial-kemasyarakatan

Kegiatan produksi harus menjaga nilai-nilai keseimbangan dan harmoni dengan lingkungan sosial dan lingkungan hidup dalam masyarakat dalam skala yang lebih luas. Selain itu, masyarakat juga berhak menikmati hasil produksi secara memadai dan berkualitas. Jadi produksi bukan hanya menyangkut kepentingan para produsen (staock holders) saja tapi juga masyarakat secara keseluruhan (stake holders). Pemerataan manfaat dan keuntungan produksi bagi keseluruhan masyarakat dan dilakukan dengan cara yang paling baik merupakan tujuan utama kegiatan ekonomi.

5. Permasalahan ekonomi muncul bukan saja karena kelangkaan tetapi lebih kompleks. ${ }^{9}$

Masalah ekonomi muncul bukan karena adanya kelangkaan sumber daya ekonomi untuk pemenuhan kebutuhan manusia saja, tetapi juga disebabkan oleh kemalasan dan pengabaian optimalisasi segala anugerah Allah, baik dalam bentuk sumber daya alam maupunmanusia. Sikap terserbut dalam Al-Qur'an sering disebut sebagai kezaliman atau pengingkaran terhadap nikmat Allah ${ }^{10}$. Hal ini akan membawa implikasi bahwa prinsip produksi bukan sekedar efisiensi, tetapi secara luas adalah bagaimana mengoptimalisasikan pemanfaatan sumber daya ekonomi dalam kerangka pengabdian manusia kepada Tuhannya.

Kegiatan produksi dalam perspektif Islam bersifat alturistik sehingga produsen tidak hanya mengejar keuntungan maksimum saja. Produsen harus mengejar tujuan yang lebih luas sebagaimana tujuan ajaran Islam yaitu falah didunia dan akhirat. Kegiatan produksi juga harus berpedoman kepada nilainilai keadilan dan kebajikan bagi masyarakat. Prinsip pokok produsen yang Islami yaitu: 1. memiliki komitmen yang penuh terhadap keadilan, 2. memiliki dorongan untuk melayani masyarakat sehingga segala keputusan 
perusahaan harus mempertimbangkan hal ini, 3. optimasi keuntungan diperkenankan dengan batasan kedua prinsip di atas.

\section{Faktor-faktor Produksi ${ }^{11}$}

Produksi tidak akan dapat dilakukan kalau tidak ada bahan-bahan yang memungkinkan dilakukannya proses produksi itu sendiri. Untuk bisa melakukan produksi, orang memerlukan tenaga manusia, sumber-sumber alam, modal dalam segala bentuknya, serta kecakapan. Jadi, semua unsur yang menopang usaha penciptaan nilai atau usaha memperbesar nilai barang disebut sebagai faktor-faktor produksi. ${ }^{12}$ Seorang produsen dalam menghasilkan suatu produk harus mengetahui jenis atau macam-macam dari faktor produksi. ${ }^{13}$ Macam faktor produksi secara teori terbagi menjadi empat, yaitu sebagai berikut:

1. Tanah

Hal yang dimaksud dengan istilah land atau tanah di sini bukanlah sekedar tanah untuk ditanami atau untuk ditinggali saja, tetapi termasuk pula di dalamnya segala sumber daya alam (natural resources). Dengan demikian, istilah tanah atau land ini maksudnya adalah segala sesuatu yang bisa menjadi factor produksi berasal dan atau tersedia di ala mini tanpa usaha manusia, yang antara lain meliputi:

- Tenaga penumbuh yang ada di dalam tanah, baik untuk pertanian, perikanan, maupun pertambangan.

- Tenaga air, baik untuk pengairan maupun pelayaran. Termasuk juga di sini adalah air yang dipakai sebagai bahan pokok oleh Perusahaan Air Minum.

- Ikan dan mineral, baik ikan dan mineral darat (sungai, danau, tambak, dan sebagainya) maupun ikan dan mineral laut.

- Tanah yang di atasnya didirikan bangunan.

- Living stock, seperti ternak dan binatang-binatang lain yang bukan ternak.

- Dan lain-lain, seperti bebatuan dan kayu-kayuan.

Berkaitan dengan faktor produksi ini dalam sebuah hadis disebutkan: Imam Abu Dawud meriwayatkan dalam Sunannya: Telah memberitahu kami Ali bin Ja'ad al-Lu'lu'iy. Telah memberitahu kami Hariz bin Ustman, dari Hibban bin Zaid al-Syar'abiy, dari laki-laki yang berasal dari Qarn. Telah memberitahu kami Musaddad. Telah memberitahu kami Isa bin Yunus. Telah memberitahu kami Hariz bin Ustman. Telah memberitahu kami Abu Khidasy. Dan ini adalah lafadh Ali dari laki-laki di antara kaum Muhajirin, di antara 
sahabat Nabi saw. Ia berkata saya mengikuti Nabi saw berperang sebanyak tiga kali, sedang saya mendengar beliau bersabda:

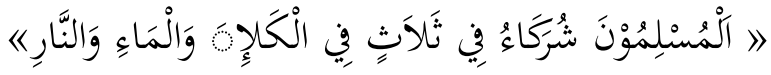

"Kaum Muslim berserikat dalam tiga hal, yaitu padang rumput, air dan api. “

- "Dalam air": Maksudnya adalah air yang tidak terjadi dari pencarian dan usaha seseorang, seperti air saluran pribadi, dan air sumur, serta belum dimasukkan dalam wadah, kolam atau selokan yang airnya dari sungai.

- "Padang rumput": Maksudnya adalah semua tumbuhan atau tanaman yang basah maupun yang kering.

- "Dan dalam Api“. Maksud dari berserikat dalam api adalah, bahwa ia tidak dilarang menyalakan lampu darinya, dan membuat penerangan dengan cahayanya, namuan orang yang menyalakannya dilarang untuk mengambil bara api dirinya, sebab menguranginya akan menyebabkan pada padamnya api.

\section{Keunikan Tanah Dalam Islam}

Tanah dan alam merupakan salah satu faktor produksi yang sangat penting. Oleh karena itu, sangat tepat kalau Islam memberikan perhatian yang besar terhadapnya. Dan tidak mengherankan kalau ada orang barat yang mengatakan bahwa "tanah adalah ibu dari produksi, sementara ayahnya adalah tenaga kerja".

Keunikan dari faktor produksi tanah dibanding yang lainnya adalah sebagai berikut: a).Tanah adalah pemberian langsung dari Allah SWT dalam artian kita hanya tinggal menerima dan memanfaatkan saja. Berbeda dengan tenaga kerja dan kapital yang itu diperoleh dari kerja keras atau usaha dari manusia. Oleh karena tanah diberikan oleh Allah SWT secara langsung maka penggunaannya tidak boleh sembarangan, yaitu harus sesuai dengan ketentuan yang Allah berikan kepada kita.

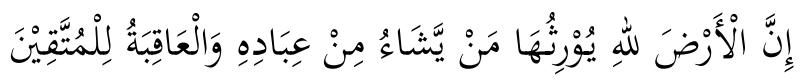

Artinya: "sesungguhnya bumi (ini) kepunyaan Allah; dipusakakan-Nya kepada siapa yang dikehendaki-Nya dari hamba-hamba-Nya. Dan kesudahan yang baik adalah bagi orang-orang yang bertakwa." (Al A'rof 128) 
b). Eksistensi dari tanah adalah sesuatu yang sangat kompleks. Kalau kita lihat sumber daya yang diberikan oleh tanah adalah yang ada didalam dan permukaan tanah itu sendiri. Dari bawah tanah maka tanah memberikan bahan-bahan mineral dan tambang yang bermanfaat bagi manusia, sedang dari permukaan tanah juga memberikan manfaat yang luar biasa pada kita semua.

c). Penyediaan atau penawaran tanah relatif terbatas, dalam artian bahwa tanah telah memiliki jumlah keseluruhan yang tertentu, tidak dapat ditambah maupun dikurangi.

\section{Tenaga kerja}

Dalam ilmu ekonomi yang dimaksud dengan istilah tenaga kerja manusia (labor) bukanlah semata-mata kekuatan manusia untuk mencangkul, menggergaji, bertukang, dan segala kegiatan fisik lainnya, akan tetapi lebih luas lagi yaitu human resources (sumber daya manusia). Di dalam istilah human resources atau SDM itu tercakuplah tidak saja tenaga fisik atau tenaga jasmani manusia tetapi juga kemampuan mental atau kemampuan nonfisiknya, tidak saja tenaga terdidik tetapi juga tenaga yang tidak terdidik, tidak saja tenaga yang terampil tetapi juga yang tidak terampil. Pendek kata, di dalam istilah atau pengertian human resources itu terkumpullah semua atribut atau kemampuan manusiawi yang dapat disumbangkan untuk memungkinkan dilakukannya proses produksi barang dan jasa.

Konsep upah menurut kaca Islam, adalah pertama, prinsip keadilan, dan kedua, prinsip kelayakan (kecukupan). Mari kita lihat kedua prinsip ini dari kaca mata Islam, yaitu :

a. Prinsip Adil

Al Qur'an menegaskan bahwa:

"Berbuat adillah, karena adil itu lebih dekat kepada Taqwa”. (QS. Al-Maidah : 8).

"Hai orang-orang yang beriman, apabila kamu bemua'malah tidak secara tunai untuk waktu yang ditentukan, hendaklah kamu menuliskannya. Dan hendaklah seorang penulis diantara kamu menuliskannya dengan benar. Dan janganlah penulis enggan menuliskannya sebagaimana Allah mengajarkannya, maka hendaklah ia menulis dan hendaklah orang yang berhutang itu mengimlakkan (apa yang akan ditulis itu), dan hendaklah ia bertaqwa kepada Allah Tuhannya, dan janganlah ia mengurangi sedikitpun daripada hutangnya. Jika yang berhutang itu orang yang lemah akalnya atau lemah (keadaannya) atau dia sendiri tidak mampu mengimlakkan, maka hendaklah walinya mengimlakkan dengan jujur. Dan persaksikanlah 
dengan dua orang saksi dari orang-orang lelaki diantaramu. Jika tak ada dua orang lelaki, maka (boleh) seorang lelaki dan dua orang perempuan dari saksi-saksi yang kamu ridhai, supaya jika seorang lupa maka seorang lagi mengingatkannya. Janganlah saksi-saksi itu enggan (memberi keterangan) apabila mereka di panggil; dan janganlah kamu jemu menulis hutang itu, baik kecil maupun besar sampai batas waktu membayarnya. Yang demikian itu, lebih adil di sisi Allah dan lebih dekat kepada tidak (menimbulkan) keraguanmu. (Tulislah mua'malahmu itu), kecuali jika mua'malah itu perdagangan tunai yang kamu jalankan di antara kamu, (jika) kamu tidak menulisnya. Dan persaksikanlah apabila kamu berjual beli; dan janganlah penulis dan saksi saling sulitmenyulitkan. Jika kamu lakukan (yang demikian), maka sesungguhnya hal itu adalah suatu kefasikan pada dirimu. Dan bertaqwalah kepada Allah; Allah mengajarmu; dan Allah Maha Mengetahui segala sesuatu.” (QS. Al-Baqarah : 282)

Nabi bersabda:"Berikanlah gaji kepada pekerja sebelum kering keringatnya, dan beritahukan ketentuan gajinya, terhadap apa yang dikerjakan". (HR. Baihaqi).

Dari ayat Al-Qur'an dan hadits riwayat Baihaqi di atas, dapat diketahui bahwa prinsip utama keadilan terletak pada kejelasan aqad (transaksi) dan komitmen atas dasar kerelaan melakukannya (dari yang ber-aqad). Aqad dalam perburuhan adalah aqad yang terjadi antara pekerja dengan pengusaha. Artinya, sebelum pekerja dipekerjakan, harus jelas dahulu bagaimana upah yang akan diterima oleh pekerja. Upah tersebut meliputi besarnya upah dan tata cara pembayaran upah.

Khusus untuk cara pembayaran upah, Rasulullah bersabda: "Dari Abdillah bin Umar, Rasulullah Saw. Bersabda: "Berikanlah upah orang upahan sebelum kering keringatnya". (HR.Ibnu Majah dan Imam Thabrani).

Dalam menjelaskan hadits itu, Syeikh Yusuf Qardhawi dalam kitabnya Pesan Nilai dan Moral dalam Perekonomian Islam, menjelaskan sebagai berikut : Sesungguhnya seorang pekerja hanya berhak atas upahnya jika ia telah menunaikan pekerjaannya dengan semestinya dan sesuai dengan kesepakatan, karena umat Islam terikat dengan syaratsyarat antar mereka kecuali syarat yang mengharamkan yang halal atau menghalalkan yang haram. Namun, jika ia membolos bekerja tanpa alasan yang benar atau sengaja menunaikannya dengan tidak semestinya, maka sepatutnya hal itu diperhitungkan atasnya (dipotong upahnya) karena setiap hak dibarengi dengan kewajiban. Selama ia mendapatkan upah 
secara penuh, maka kewajibannya juga harus dipenuhi. Sepatutnya hal ini dijelaskan secara detail dalam "peraturan kerja" yang menjelaskan masing-masing hak dan kewajiban kedua belah pihak. Bahkan Syeikh Qardhawi mengatakan bahwa bekerja yang baik merupakan kewajiban karyawan atas hak upah yang diperolehnya, demikian juga memberi upah merupakan kewajiban perusahaan atas hak hasil kerja karyawan yang diperolehnya. Dalam keadaan masa kini, maka aturan-aturan bekerja yang baik itu, biasanya dituangkan dalam buku Pedoman Kepegawaian yang ada di masing-masing perusahaan.

Hadits lain yang menjelaskan tentang pembayaran upah ini adalah: "Diriwayatkan dari Abu Hurairah r.a., dari Nabi Muhammad Saw. bahwa beliau bersabda: "Allah telah berfirman: "Ada tiga jenis manusia dimana Aku adalah musuh mereka nanti di hari kiamat. Pertama, adalah orang yang membuat komitmen akan memberi atas nama-Ku (bersumpah dengan nama-Ku), kemudian ia tidak memenuhinya. Kedua, orang yang menjual seorang manusia bebas (bukan budak), lalu memakan uangnya. Ketiga, adalah orang yang menyewa seorang upahan dan mempekerjakan dengan penuh, tetapi tidak membayar upahnya" (HR. Bukhari).

Hadits diatas menegaskan tentang waktu pembayaran upah, agar sangat diperhatikan. Keterlambatan pembayaran upah, dikategorikan sebagai perbuatan zalim dan orang yang tidak membayar upah para pekerjanya termasuk orang yang dimusuhi oleh Nabi saw pada hari kiamat. Dalam hal ini, Islam sangat menghargai waktu dan sangat menghargai tenaga seorang karyawan (buruh).

b. Kelayakan (kecukupan)

Jika Adil berbicara tentang kejelasan, transparansi serta proporsionalitas ditinjau dari berat pekerjaannya, maka Layak berhubungan dengan besaran yang diterima layak disini bermakna cukup dari segi pangan, sandang dan papan.

Dari hadits yang diriwayatkan oleh Abu Dzar bahwa Rasulullah SAW bersabda: "Mereka (para budak dan pelayanmu) adalah saudaramu, Allah menempatkan mereka di bawah asuhanmu; sehingga barang siapa mempunyai saudara di bawah asuhannya maka harus diberinya makan seperti apa yang dimakannya (sendiri) dan memberi pakaian seperti apa yang dipakainya (sendiri); dan tidak membebankan pada mereka dengan tugas yang sangat berat, dan jika kamu membebankannya dengan tugas seperti itu, maka hendaklah membantu mereka (mengerjakannya)." (HR. Muslim). 
Dapat dijabarkan bahwa hubungan antara majikan dengan pekerja bukan hanya sebatas hubungan pekerjaan formal, tetapi karyawan sudah dianggap merupakan keluarga majikan. Konsep menganggap karyawan sebagai keluarga majikan merupakan konsep Islam yang lebih dari 14 abad yang lalu telah dsabdakan oleh Nabi Muhammad SAW. Konsep ini dipakai oleh pengusaha-pengusaha Arab pada masa lalu, dimana mereka (pengusaha muslim) seringkali memperhatikan kehidupan karyawannya di luar lingkungan kerjanya. Hal inilah yang sangat jarang dilakukan saat ini.

Wilson menulis dalam bukunya yang berjudul Islamic Business Theory and Practice yang kurang lebih maksudnya adalah "Walaupun perusahaan itu bukanlah perusahaan keluarga, para majikan Muslimin acapkali memperhatikan kehidupan karyawan di luar lingkungan kerjanya, hal ini sulit untuk dipahami oleh para pengusaha Barat". Sahabat pengusaha yang diridhai Allah SWT, konsep Islam jauh sangat berbeda dengan konsep upah menurut Barat. Upah menurut Islam sangat besar kaitannya dengan konsep Moral, Upah dalam Islam tidak hanya sebatas materi (kebendaan atau keduniaan) tetapi menembus batas kehidupan, yakni berdimensi akherat (pahala). Jadi mulai dari sekarang, marilah kita terapkan prinsip Islam kembali.

3. Modal

Modal (capital) yaitu meliputi semua jenis barang yang dibuat untuk menunjang kegiatan produksi barang-barang lain serta jasa-jasa. Termasuk ke dalam bilangan barang-barang modal misalnya mesinmesin, pabrik-pabrik, jalan-jalan raya, pembangkit tenaga listrik, gudang serta semua peralatannya. Modal juga mencakup arti uang yang tersedia di dalam perusahaan untuk membeli mesin-mesin, serta faktor-faktor produksi lainnya.

Pembahasan mengenai modal yang merupakan salah satu faktor produksi dalam ekonomi Islam, adalah terkait dengan masalah kepemilikan harta. Sedangkan pengembangannya itu sendiri tidak akan lepas dari suatu mekanisme yang dipergunakan seseorang untuk menghasilkan pertambahan kepemilikan tersebut. Dan dalam hal ini Islam menyerahkan masalah pengembangan harta (mekanisme yang dipakai) tersebut kepada individu sesuai pandangan yang menurutnya layak dipergunakan. Konsep pengembangan modal produksi dalam ekonomi Islam dapat ditinjau dari beberapa segi yaitu:

a. Sistem Pengembangan

Sistem pengembangan modal dalam ekonomi Islam (termasuk modal produksi) sangat terkait dengan konsep kepemilikan Islam. Menurut 
Islam, kepemilikan pada dasarnya adalah sebagai naluri alamiah yang dimiliki manusia dan hanya berfungsi sebagai sarana penunjang untuk mencapai tujuan yang lebih besar, karena semua yang ada di muka bumi (termasuk harta) adalah milik Allah Swt. Sehingga, dalam konsep ekonomi Islam kepemilikan itu haruslah merata dan tidak terfokus pada beberapa golongan saja dan di dalam mendapatkan dan mengembangkannya haruslah melalui cara-cara yang sesuai dengan ketentuan ajaran agama. Dalam hal ini, ekonomi Islam memberikan batasan-batasan sebagai berikut: Cara mendapatkan modal (harta) dan mengembangkannya tidak dilakukan dengan yang dilarang Syari'at Islam. Antara lain pertama, dengan jalan perjudian, karena cara ini dapat menimbulkan permusuhan dan dapat merusak tatanan kehidupan masyarakat. Pada dasarnya cara pengembangan ini dilakukan tanpa adanya usaha yang jelas dan hanya bersifat spekulasi semata. Kedua, pengembangan harta/pengembangan harta/modal dengan jalan riba (apapun 6 bentuk dan jumlahnya), yaitu pengambilan keuntungan dengan cara mengeksploitasi tenaga orang lain. Ketiga, pengembangan modal dengan jalan penipuan (al-ghabn atau at-tadlis). Cara-cara penipuan dalam segala kegiatan ekonomi yang dilakukan di masyarakat jelas-jelas dilarang dan diharamkan agama. Keempat, pengembangan modal (harta) dengan jalan penimbunan. Maksudnya adalah seseorang mengumpulkan barang-barang dengan tujuan menunggu waktu naiknya harga barang-barang terebut, sehingga ia bisa menjualnya dengan harga tinggi menurut kehendaknya.

b. Menentukan mekanisme pengembangan dan pengelolaannya, di mana dalam mekanisme ini harus jelas cara atau bentuk serta tujuan yang akan dicapai. Prinsipnya adalah peningkatan dan pembagian hasil untuk menciptakan sirkulasi yang benar dan tepat bagi setiap golongan masyarakat dengan latar belakang perekonomian yang berbeda.

c. Hak milik pribadi kadangkala dalam keadaan tertentu dapat berubah menjadi milik umum. Di antara hal penting yang diungkapkan ajaran Islam adalah penetapan antara pemilikan bersama menyangkut benda-benda yang bersifat dharuri (yang sangat dibutuhkan bagi semua manusia), sehingga kepemilikannya bersifat bersama dan umum. 
d. Mensuplai atau memberikan orang yang memiliki keterbatasan faktor-faktor produksi dengan ketentuan-ketentuan yang ada, seperti memberikan pinjaman modal untuk digunakan sebagai modal usaha sehingga dapat dikembangkan lagi menjadi lebih besar, ataupun dengan memberikan modal kepada seseorang dengan perjanjian membagi hasil yang didapat sesuai perjanjian.

\section{Bentuk Pengembangan Modal}

Dalam proses produksi, bentuk pengembangan modal secara umum dilakukan melalui aktivitas transaksi (akad) dengan tetap memegang aturan Syari'ah yang terkait. Prinsip utama dalam pengembangan dan pendaya-gunaan suatu modal dalam ekonomi Islam adalah peningkatan dan pembagian hasil, dengan tujuan agar tercipta sirkulasi yang merata dalam masyarakat. Tujuan keadilan sosio-ekonomi dan pemerataan pendapatan sudah jelas dianggap sebagai bagian yang tidak terpisahkan dari filsafat moral Islam dengan komitmennya pada keadilan dan persaudaran manusia. Adapun bentuk-bentuk pengembangan modal menurut ketentuan Syari'ah Mu'amalah, dapat dilakukan dalam bentuk atau pola sebagai berikut:

a. Transaksi akad jual-beli, yaitu pengembangan modal usaha di mana seseorang berada dalam posisi sebagai penjual dan yang lainnya sebagai pembeli, seperti dalam akad al-Ba'i, as-Salam, dan al-Istinsya'.

b. Transaksi akad bagi-hasil, yaitu pengembangan modal usaha di mana seseorang dapat bertindak sebagai pemberi modal dan yang lainnya bertindak sebagai pengelola modal dengan kerentuan akan membagi hasil yang diperoleh sesuai perjanjian yang telah disepakati. Transaksi ini dapat dilihat dalam akad-akad bagi hasil seperti dalam akad as-syirkah seperti akad al-Mudharabah dan akad as-Syirkah.

c. Transaksi akad jasa, yaitu pengembangan modal di mana seseorang bertindak sebagai konsumen/pemakai jasa dan wajib memberikan harga kepada pihak yang telah memberikan jasa tersebut menurut kesepakatan yang dibuat, seperti dalam akad al-rahn, al-wadi'ah. Dengan demikian langkah-langkah yang perlu dilakukan dalam upaya mengembangkan dan mendaya-gunakan modal produksi ini, dapat direalisasikan antara lain dengan cara: (1) mengadakan perjanjian Qardh al-Hasan dengan suatu bank Syari'ah yang ada untuk tujuan sosial dengan memberikan pinjaman yang lunak kepada golongan ekonomi yang lemah (khususnya) berupa fasilitas modal usaha, agar mereka dapat memiliki usaha yang tetap dan dapat dikembangkan dengan baik. (2) Mengadakan berbagai larangan terhadap segala bentuk praktek bisnis yang tidak sehat dalam masyarakat, seperti perjudian, riba dan lain sebagainya, dan mewujudkan proses distribusi melalui wadah zakat, infaq dan shadaqah (yang dikelola oleh Bazis) dengan tujuan untuk memenuhi hak-hak 
sosial masyarakat lainnya. Dalam hal ini peran pemerintah (institusi yang berwenang) dibutuhkan untuk mewujudkannya.

Dengan demikian, dengan adanya pengembangan modal usaha yang dilakukan sesuai dengan sistem ekonomi Islam, diharapkan akan tercipta kondisi perekonomian masyarakat yang kondusif bagi pengembangan produksi. Kepemilikan atas faktor-faktor produksi dalam jumlah besar (khususnya modal) dapat dibatasi dan terkontrol dengan baik untuk menghindari tindakan sewenang-wenang pemilik modal terhadap mereka yang sangat butuh terhadap faktor produksi tersebut.

\section{Kecakapan Tata Laksana (Manajemen)}

Kecakapan (skiil) yang menjadi faktor produksi keempat ini disebut juga deangan sebutan entrepreneurship. Entrepreneurship ini merupakan faktor produksi yang intangible (tidak dapat diraba), tetapi sekalipun demikian peranannya justru amat menentukan. Seorang entrepreneurship mengorganisir ketiga faktor produksi lainnya agar dapat dicapai hasil yang terbaik. Ia pun menanggung resiko untuk setiap jatuh bangun usahanya. Tidak pelak lagi bahwa faktor produksi yang keempat ini adalah yang terpenting di antara semua faktor produksi. Memang ia tidak bisa dilihat, tetapi setiap orang mengetahui dan merasakan bahwa ia, entrepreneurship atau managerial skill itu, adalah amat penting peranannya sehubungannya dengan yang dihasilkan.

Keempat faktor produksi yang telah disebutkan di atas, adalah unsur-unsur yang harus bekerja demi terlaksananya proses produksi. Apabila keempatnya adalah kita misalkan makhluk-makhluk yang dapat berpikir dan merasa, keempatnya adalah tanah, tenaga manusia, modal, dan tata laksana semuanya itu akan minta dan menuntut balas jasa atas hasil kerjanya. Kepada faktor produksi tanah dibayarkan sewa (rent). Untuk tenaga manusia (labor) dikenal tiga jenis pembayaran balas jasa, yaitu upah (wage), gaji (salary), dan royalty. Untuk modal dibayarkan bunga (interest) dan deviden.

\section{Produksi dalam Al Quran}

Al Quran surat Ibrahim ayat 32-34.

1. Allah-lah yang Telah menciptakan langit dan bumi dan menurunkan air hujan dari langit, Kemudian dia mengeluarkan dengan air hujan itu berbagai buah-buahan menjadi rezki untukmu; dan dia Telah menundukkan bahtera bagimu supaya bahtera itu, berlayar di lautan dengan kehendak-Nya, dan dia Telah menundukkan (pula) bagimu sungai-sungai.

2. Dan dia Telah menundukkan (pula) bagimu matahari dan bulan yang terus menerus beredar (dalam orbitnya); dan Telah menundukkan bagimu malam dan siang. 
3. Dan dia Telah memberikan kepadamu (keperluanmu) dan segala apa yang kamu mohonkan kepadanya. dan jika kamu menghitung nikmat Allah, tidaklah dapat kamu menghinggakannya. Sesungguhnya manusia itu, sangat zalim dan sangat mengingkari (nikmat Allah).

4. Konsep Hak Milik dalam Islam. Hak milik merupakan setiap individu manusiawi, fitrah yang melekat dalam setiap individu yang tidak bisa dihilangkan karena telah menjadi kebutuhan jiwa dalam kehidupan. ${ }^{14}$ Al Quran memandang harta dengan pandangan yang realitis. Dinyatakan harta itu pandangan hidup dan kecintaan terhadap harta sebagai tabiat manusia. Firman Allah dalam QS Al Kahfi: 46

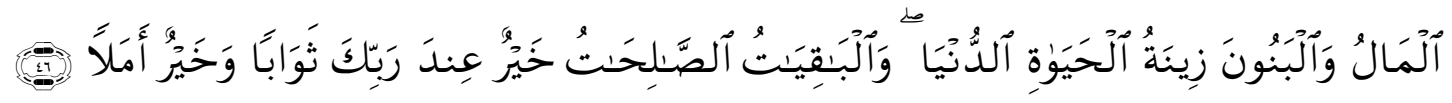

"Harta dan anak-anak adalah perhiasan kehidupan dunia tetapi amalan-amalan yang kekal lagi saleh adalah lebih baik pahalanya di sisi Tuhanmu serta lebih baik untuk menjadi harapan."

Dan dalam QS Al Adiyat: 8

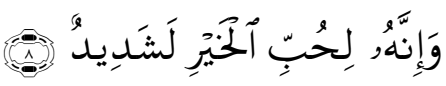

"Dan Sesungguhnya dia (manusia) sangat bakhil karena cintanya kepada harta."

Hak milik adalah amanat, pemilik yang sebenarnya adalah Allah SWT sendiri. Hak manusia untuk memanfaatkan barang-barang di dunia adalah dalam kedudukannya sebagai khalifah dan pengemban amanat Allah. ${ }^{15}$ Hal ini sesuai dengan QS Al Baqarah: 284

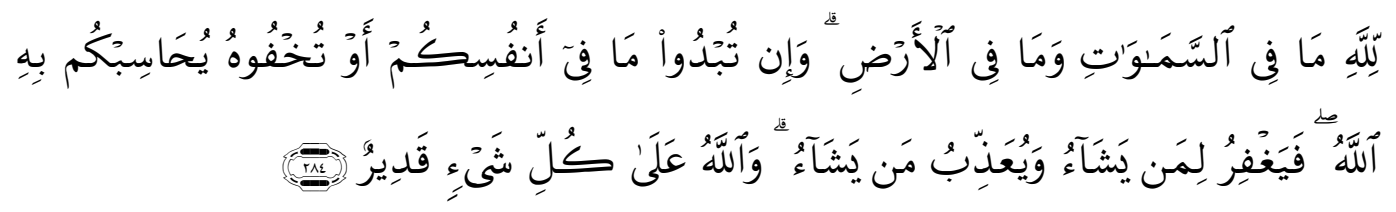

"Kepunyaan Allah-lah segala apa yang ada di langit dan apa yang ada di bumi. dan jika kamu melahirkan apa yang ada di dalam hatimu atau kamu menyembunyikan, niscaya Allah akan membuat perhitungan dengan kamu tentang perbuatanmu itu. Maka Allah mengampuni siapa yang dikehandaki-Nya dan menyiksa siapa yang dikehendaki-Nya; dan Allah Maha Kuasa atas segala sesuatu."

Menurut Mustafa Husin al-Siba'I, Allah telah menjadikan harta sebagai perantara untuk memperoleh kebaikan. Oleh sebab itu, harta digunakan untuk kebaikan atau utuk kepentingan masyarakat. ${ }^{16}$ Muhammad al Mubarak menyebutkan ada tiga hal sebab dari pemilikan, sebab-sebab pemilikan itu meliputi: 
1. Pemilikan dari hasil usaha individual. Hal ini yang dibenarkan secara syara' seperti usaha bertani, berdagang, berburu, dan lain-lain.

2. Pemilikan tanpa diusahakan yang ditetapkan syara', seperti hak atas nafkah, warisan, dan zakat.

3. Pertukaran pemilikan seperti menukarkan uang dengan pakaian.

Dari beberapa literatur yang membahas tentang hak milik, ada dua kategori hak milik. Kategori pertama, membagi hak milik menurut sifat umum dan khusus pemilikannya. Hak milik umum ialah pemilikan oleh umum dan manfaatnya untuk seluruh individu. ${ }^{17}$ Pemanfaatan hak milik umum dilakukan dan diatur oleh Negara, karena Negara sebagai penanggung jawab atas keberadaan distribusi dan pemanfaatannya. Pengelolaan hak milik umum ini bisa dilakukan oleh pihak swasta, namun harus mendapatkan izin negara selaku penanggung jawab. Hak milik umum ditetapkan berdasarkan atas manfaat umum, sebab pemilikan atau penguasaan oleh sekelompok orang bisa berdampak negatif. Dalam hak milik umum ini, negara bertindak sebagai caretaker atau pemegang amanat publik.

Pandangan yang lain menyebutkan hak milik umum adalah hak milik negara. Pandangan ini menyebut fasilitas umum seperti, jalan, air sungai dan laut, bahan tambang, tanah, dan lain-lain adalah millik negara. Pandangan ini berlaku umum di kalangan para ahli dan pemikir Islam. Oleh Ibnu Taymiyah, hak milik seperti ini adalah hak milik sosial. Menurutnya, hak milik negara itu meliputi zakat, waqaf, harta rampasan perang, pajak, dan denda. ${ }^{18}$ Hak milik negara atau sumber kekayaan untuk penyelenggaraan tugas atau kewajiban negara seperti, penyelenggaraan pendidikan dan penegakkan keadilan.

Melengkapi uraian tentang hal milik umum ini, maka akan dikemukakan beberapa landasan hukum hak milik umum, yaitu QS Al Baqarah: 29

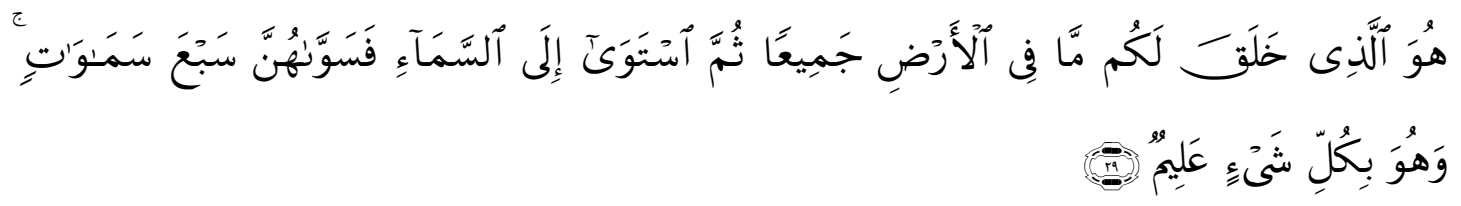

"Dia-lah Allah, yang menjadikan segala yang ada di bumi untuk kamu dan Dia berkehendak (menciptakan) langit, lalu dijadikan-Nya tujuh langit. dan Dia Maha mengetahui segala sesuatu."

Dan QS. Al A'Raf: 10

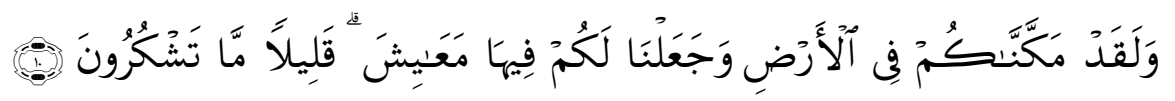

"Sesungguhnya Kami telah menempatkan kamu sekalian di muka bumi dan Kami adakan bagimu di muka bumi (sumber) penghidupan. Amat sedikitlah kamu bersyukur." 
Rasulullah saw pada sebuah peperangan pernah bersabda kepada seorang sahabat: "Dari seorang sahabat Rasulluah saw, dia berkata, Rasulullah saw bersabda: "Semua orang berserikat dalam tiga hal, yaitu dalam hal (pemanfaatan atau pemilikan) rumput, air, dan api.” (HR. Ahmad).

Hadits tersebut mengandung arti bahwa air, rumput, dan api tidak boleh dimonopoli oleh seseorang atau sekelompok orang. Dengan kata lain, setiap orang berhak dan dibenarkan untuk memiliki barang-barang ini. Air, rumput, dan api diartikan sebagai barang yang dapat mewakili barang-barang lain. Karenanya, pembatasan pemilikan tidak hanya berlaku atas barang-barang ini, tetapi juga berlaku untuk barang-barang lain yang sejenis atau yang menurut pandangan tertentu memiliki kualifikasi yang sama. Berdasarkan hadist ini dapat dipahami bahwa tidak ada monopoli individu terhadap barang-barang seperti rumput, air, dan api, sebab barang tersebut adalah barang kebutuhan pokok di masa Rasulullah saw.

Hak milik khusus adalah pemilikan atas sesuatu oleh seseorang dan sekelompok orang secara bersama-sama. ${ }^{19}$ Hak milik khusus ini meliputi hak milik individual dan kolektif. Dalam hak milik terdapat aturan-aturan kemaslahatan umum dan aturan pemanfaatan hak milik yang baik. Hak milik individual merupakan salah satu asas penting dalam Islam.

Dalam sistem ekonomi Islam, perolehan dan pemanfaatan hak milik harus dengan jalan ma'aruf. Di dalam harta itu terdapat hak-hak kemasyarakatan yang harus ditunaikan. Al-Qur'an menegaskan dalam surat Al Baqarah: 188

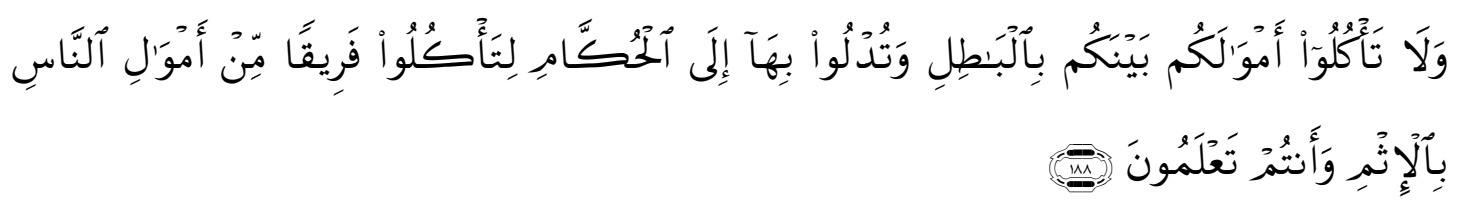

"Dan janganlah sebahagian kamu memakan harta sebahagian yang lain di antara kamu dengan jalan yang bathil dan (janganlah) kamu membawa (urusan) harta itu kepada hakim, supaya kamu dapat memakan sebahagian daripada harta benda orang lain itu dengan (jalan berbuat) dosa, Padahal kamu mengetahui."

Dengan demikian maka jelaslah bahwa sistem ekonomi Islam merupakan sistem ekonomi yang adil serta berupaya menjamin kekayaan tidak terkumpul hanya pada satu individu atau kelompok, tetapi tersebar keseluruh masyarakat.

\section{Distribusi dan Permasalahannya}

\section{a. Pengertian Distribusi}

Distribusi adalah suatu proses penyampaian barang atau jasa dari produsen ke konsumen dan para pemakai. ${ }^{20}$ Saluran distribusi adalah suatu jalur perantara pemasaran dalam berbagai aspek barang atau jasa dari tangan produsen ke konsumen. Antara pihak produsen dan konsumen terdapat 
perantara pemasaran, yaitu wholesaler (distributor atau agen) yang melayani pembeli. $^{21}$

\section{b. Konsepsi umum Fikih Islam mengenai distribusi dan redistribusi}

Pada dasarnya distribusi pendapatan dan kekayaan berdasarkan maslahat dan batas waktu, sementara distribusi pendapatan dilandasi oleh produksi, barter, dan pertimbangan-pertimbangan pasar. Sedangkan redistribusi berlandaskan pada pertimbangan keagamaan, moral, keluarga dan sosial (atau biasanya disebut transformasi sosial) ${ }^{22}$.

Melalui analisis induktif terhadap hukum Islam, Qal'aji ${ }^{23}$ memaparkan bahwa Sumber Daya Alam yang merupakan sumber kekayaan sesungguhnya milik Allah. Namun kepemilikan Tuhan ini diamanahkan kepada manusia dengan mekanisme kerja. SDA ini pada kenyataannya ada yang telah dimiliki manusia dan ada yang belum bertuan.

Secara garis besar, redistribusi kekayaan dan pendapatan dalam Islam dikenal melalui tujuh cara: (1) Zakat; (2) Sedekah; (3) Belanja wajib; (4) Kafarat (5) Nadzar; (6) Sembelihan; dan (7) Insentif Negara. Yang pertama, zakat yang diwajibkan hanya atas orang-orang kaya dengan ketentuan telah mencapai nisab. Adapun target redistribusinya setidaknya meliputi tiga pihak; (1) mereka yang memerlukan materi yaitu orang-orang fakir, miskin dan yang berhutang; (2) otoritas syariah Islam, melalui para pejuang di jalan Allah; dan (3) Pegawai pada lembaga zakat. Yang kedua, sedekah atau kegiatan filantrofi yang dianjurkan oleh Islam. Dalam hal ini, Rasulullah Saw. pernah bersabda, "Mâ naqasha mâlun min shadaqatin" "24 yang menyiratkan bahwa setidaknya nilai harta tidak akan berkurang bila disedekahkan, di samping itu fungsi sedekah juga dianggap sebagai tindak pencegahan terhadap instabilitas/bala bencana berdasakan pada sabda beliau yang lain, "Bâdirû bi as shadaqati fa inna al balâ lâ yatakhathâhâ". ${ }^{25}$ Yang Ketiga, belanja halal yang wajib baik dikarenakan perkawinan seperti belanja untuk isteri atau dikarenakan kebutuhan seperti belanja yang dikeluarkan untuk keluarga/kerabat faqir yang diwarisi atau untuk orang yang tidak/kehabisan bekal dalam perjalanan. ${ }^{26}$ Yang keempat, kafarat atau denda yang bentuknya bisa pembebasan hamba sahaya (untuk denda membunuh, zhihar, dan membatalkan sumpah); dalam bentuk memberikan makanan bagi orang fakir (untuk denda membatalkan sumpah, zihar bila tak mampu puasa dua bulan berturut-turut, dan denda melanggar larangan Ihram); dan dalam bentuk pemberian pakaian yang laik bagi orang fakir (denda pembatalan sumpah). Yang kelima, nadzar yaitu dalam kasus seseorang yang mewajibkan dirinya untuk melakukan perbuatan mubah karena mengagungkan Allah misalnya dengan nadzar ('komitmen') untuk bersedekah, dll. Yang keenam, daging sembelihan pada hari idul Adha. Yang ketujuh, insentif Negara yang diberikan oleh pemerintah pada saat distribusi pendapatan dan 
kekayaan tidak adil dan adanya disparitas yang sangat besar antara yang kaya dan yang miskin. ${ }^{27}$

\section{c. Tujuan Distribusi dalam Islam}

Ekonomi Islam datang dengan system distribusi yang merealisasikan beragam tujuan yang mencakup berbagai bidang kehidupan, dan mengikuti politik terbaik dalam merealisasikan tujuan - tujuan tersebut. Secara umum dapat kami katakana bahwa system distribusi ekonomi dalam ekonomi islam mempunyai andil bersama system dan politik syariah lainnya-dalam merealisasikan beberapa tujuan umum syariat islam. Dimana tujuan distribusi dalam ekonomi islam di kelompokkan kepada tujuan dakwah, pendidikan, sosial dan ekonomi. Berikut ini hal yang terpenting kedalam tujuan tersebut adalah :

\section{Pertama : Tujuan Dakwah}

Yang dimaksud dakwah disini adalah dakwah kepada islam dan menyatukan hati kepadanya. Diantaranaya contoh yang paling jelas adalah bagian muallaf di dalam zakat, dimana muallaf itu adakalnya orang kafir yang diharapkan keislamannya atau dicegah keburukannya, atau orang islam yang di harapkan kuat keislamannya. Sebagaimana system distribusi dalam ghanimah dan $f a$ ' $i$ juga memiliki tujuan dakwah yang jelas.

Pada sisi lain, bahwa pemberian zakat kepada muallaf juga memiliki dampak dakwah terhadap orang yang menunaikan zakat itu sendiri. Sebab Allah berfirman pada Firman Allah QS Ali Imran: 140

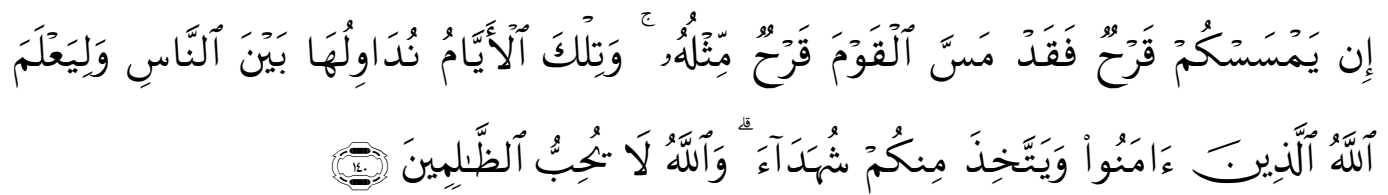

"Jika kamu (pada perang Uhud) mendapat luka, Maka Sesungguhnya kaum (kafir) itupun (pada perang Badar) mendapat luka yang serupa. dan masa (kejayaan dan kehancuran) itu kami pergilirkan diantara manusia (agar mereka mendapat pelajaran); dan supaya Allah membedakan orang-orang yang beriman (dengan orang-orang kafir) supaya sebagian kamu dijadikan-Nya (gugur sebagai) syuhada' dan Allah tidak menyukai orang-orang yang zalim,"

\section{Kedua : Tujuan Pendidikan}

Di antara tujuan pendidikan dalam distribusi adalah seperti yang di sebutkan dalam firman Allah QS At-Taubah : 103 


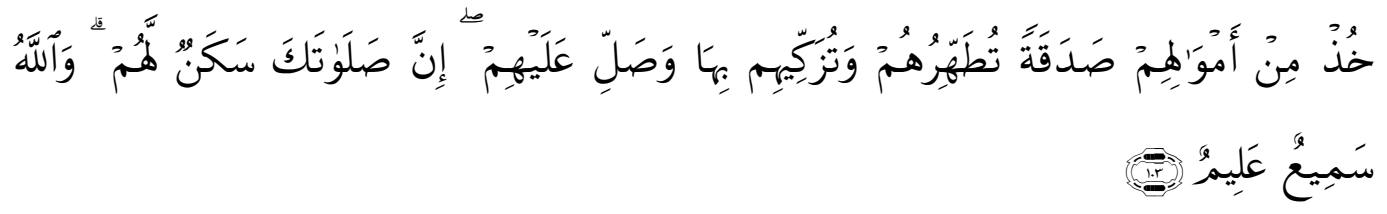

"Ambillah zakat dari sebagian harta mereka, dengan zakat itu kamu membersihkan (Maksudnya: zakat itu membersihkan mereka dari kekikiran dan cinta yang berlebih-lebihan kepada harta benda)dan mensucikan(Maksudnya: zakat itu menyuburkan sifat-sifat kebaikan dalam hati mereka dan memperkembangkan harta benda mereka) mereka dan mendoalah untuk mereka. Sesungguhnya doa kamu itu (menjadi) ketenteraman jiwa bagi mereka. dan Allah Maha mendengar lagi Maha Mengetahui."

Secara umum, bahwa distribusi dalam perspektif ekonomi islam dapat mewujudkan beberapa tujuan pendidikan, dimana yang terpenting adalah sebagai berikut :

a. Pendidikan terhadap akhlak terpuji, seperti suka memberi, berderma dan mengutamakan orang lain.

b. Mensucikan dari akhlak tercela, seperti kikir, loba dan mementingkan diri sendiri (egois).

\section{Ketiga : Tujuan Sosial}

Tujuan sosial terpenting dalam distribusi adalah sebagai berikut :

1. Memenuhi kebutuhan kelompok yang membutuhkan, dan menghidupkan prinsip solidaritas di dalam masyarakat muslim. Dapat di lihat pada Firman Allah QS Al Baqarah:273

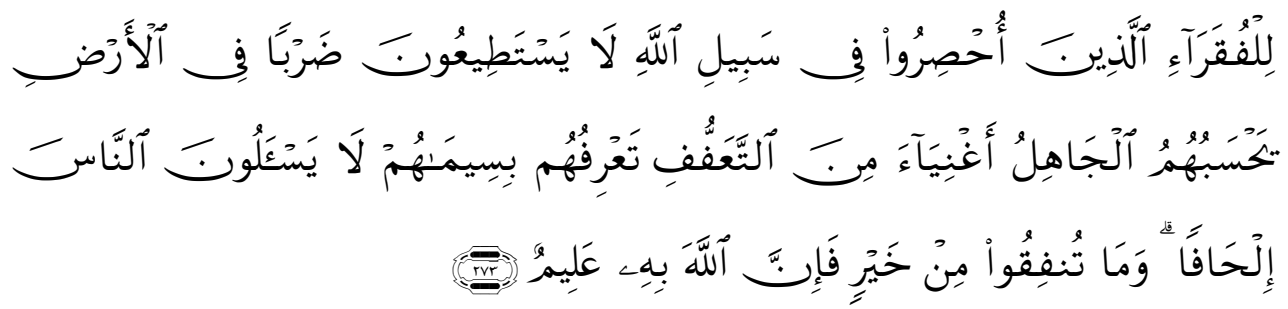

"(Berinfaqlah) kepada orang-orang fakir yang terikat (oleh jihad) di jalan Allah; mereka tidak dapat (berusaha) di bumi; orang yang tidak tahu menyangka mereka orang Kaya Karena memelihara diri dari minta-minta. kamu kenal mereka dengan melihat sifat-sifatnya, mereka tidak meminta kepada orang secara mendesak. dan apa saja harta yang baik yang kamu nafkahkan (di jalan Allah), Maka Sesungguhnya Allah Maha Mengatahui." 
2. Menguatkan ikatan cinta dan kasih sayang diantara individu dan kelompok di dalam masyarakat

3. Mengikis sebab - sebab kebencian dalam masyarakat, dimana akan berdampak pada terealisasinya keamanan dan ketentraman masyarakat, sebagai contoh bahwa distribusi yang tidak adil dalam pemasukan dan kekayaan akan berdampak adanya kelompok dan daerah miskin, dan bertambahnya tingkat kriminalitas yang berdampak pada ketidak tentraman.

4. Keadilan dalam distribusi mencakup

a. Pendistribusian sumber - sumber kekayaan

b. Pendistribusian pemasukan diantara unsur - unsur produksi

c. Pendistribusian diantara kelompok masyarakat yang ada, dan keadialan dalam pendistribusian diantara generasi yang sekarang dan generasi yang akan datang.

\section{Keempat : Tujuan Ekonomi}

Distribusi dalam ekonomi islam mempunyai tujuan - tujuan ekonomi yang penting, dimana yang terpenting diantaranya dapat kami sebutkan seperti berikut ini:

1. Pengembangan harta dan pembersihannya, karena pemilik harta ketika menginfakkan sebagian hartanya kepada orang lain, baik infak wajib maupun sunnah, maka demikian itu akan mendorongnya untuk menginvestasikan hartanya sehingga tidak akan habis karena zakat.

2. Memberdayakan sumber daya manusia yang menganggur dengan terpenuhi kebutuhannya tentang harta atau persiapan yang lazim untuk melaksanakannya dengan melakukan kegiatan ekonomi. Pada sisi lain, bahwa system distribusi dalam ekonomi islam dapat menghilangkan faktor-faktor yang menghambat seseorang dari andil dalam kegiatan ekonomi ; seperti utang yang membebani pundak orang - orang yang berhutang atau hamba sahaya yang terikat untuk merdeka. Karena itu Allah menjadikan dalam zakat bagian bagi orang-orang yang berhutang dan bagian bagi hamba sahaya.

3. Andil dalam merealisasikan kesejahteraan ekonomi, di mana tingkat kesejahteraan ekonomi berkaitan dengan tingkat konsumsi. Sedangkan tingkat konsumsi tidak hanya berkaitan dengan bentuk pemasukan saja, namun juga berkaitan dengan cara pendistribusiannya di antara individu masyarakat. Karena itu kajian tentang cara distribusi yang dapat merealisasikan tingkat kesejahteraan ekonomi terbaik bagi umat adalah suatu keharusan dan keniscayaan.

Dapat kita lihat pada QS Al-Baqarah : 265 


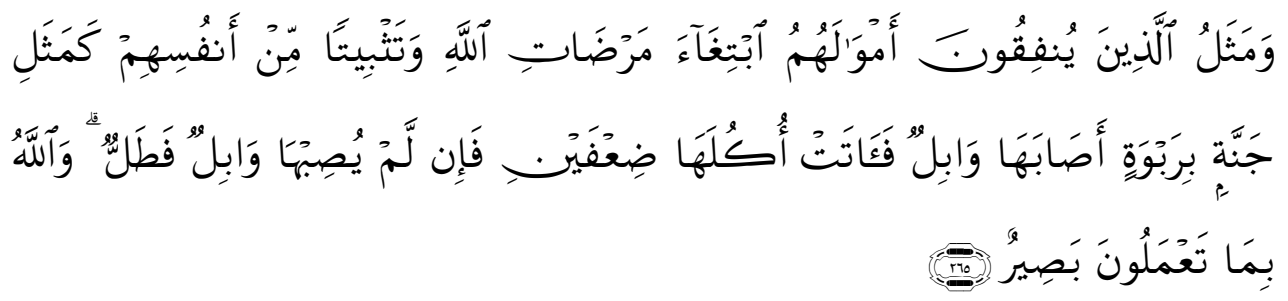

"Dan perumpamaan orang-orang yang membelanjakan hartanya Karena mencari keridhaan Allah dan untuk keteguhan jiwa mereka, seperti sebuah kebun yang terletak di dataran Tinggi yang disiram oleh hujan lebat, Maka kebun itu menghasilkan buahnya dua kali lipat. jika hujan lebat tidak menyiraminya, Maka hujan gerimis (pun memadai). dan Allah Maha melihat apa yang kamu perbuat."

Yang artinya dapat dimaknakan bahwasanya orang - orang yang membelanjakan hartanya karena keridhoaan Allah dan untuk keteguhan jiwa mereka kepada iman dan ibadah - ibadah yang lain, sebagai bentuk pelatihan kepadanya, sehingga setiap manusia terus tetap bertakwa kepada Allah SWT.

\section{Distribusi Dalam Islam}

\section{a. Zakat}

Salah satu perhatian pokok ilmu ekonomi islam adalah mewujudkan keadilan distributife.Karena itu,semua keadaan ekonomi yang didasarkan pada ketidakseimbangan (zulm) harus diganti dengan keadaan-keadaan yang memenuhi tuntutan keseimbangan. Dengan kata lain,ekonomi Islam akan berusaha memaksimalkan kesejahteraan total. Tindakan social harus digerakkan secara langsung untuk perbaikan kesejahteraan kalangan yang kurang beruntung dalam masyarakat melalui zakat,infaq serta sodaqoh.

\section{b. Warisan}

Ketika orang meninggal tidak lagi memiliki hak apa-apa atas badan dan hartanya. Sekalipun harta tersebut milik si mayit, tetapi ketika mati ia tidak berhak memberikan kepada siapa saja sesuka dia. Wasiat menyangkut harta kepada selain ahli waris hanya diperbolehkan paling banyak sepertiga bagian saja. Dengan cara ini akan berlangsung peredaran harta milik mayit kepada ahli warisnya. Dan ahli waris bisa mendapatkan harta tanpa melalui ekonomi biasa. Pribadi ahli waris dapat memperoleh harta dengan mendapatkan warisan. Dalil yang menunjukkan hal ini adalah nash al-quran yang penunjukannya secara qathiy. Waris mempunyai hukum-hukum tertentu yang sifatnya tauqify yakni suatu ketentuan hukum yang bersifat dari Allah Swt. Hukum waris juga tidak disertai illat (sebab ditetapkan hukum) apapun. Nash-nash Alquran telah menjelaskan hukum-hukum waris dalam bentuk rinci: Allah Swt telah menyatakan dalam firmannya: 
Allah mensyari'atkan bagimu tentang (pembagian pusaka untuk) anak-anakmu. Yaitu : bahagian seorang anak lelaki sama dengan bagian dua orang anak perempuan dan jika anak itu semuanya perempuan lebih dari dua, Maka bagi mereka dua pertiga dari harta yang ditinggalkan; jika anak perempuan itu seorang saja, Maka ia memperoleh separo harta. dan untuk dua orang ibu-bapa, bagi masing-masingnya seperenam dari harta yang ditinggalkan, jika yang meninggal itu mempunyai anak; jika orang yang meninggal tidak mempunyai anak dan ia diwarisi oleh ibu-bapanya (saja), Maka ibunya mendapat sepertiga; jika yang meninggal itu mempunyai beberapa saudara, Maka ibunya mendapat seperenam. (Pembagian-pembagian tersebut di atas) sesudah dipenuhi wasiat yang ia buat atau (dan) sesudah dibayar hutangnya. (Tentang) orang tuamu dan anak-anakmu, kamu tidak mengetahui siapa di antara mereka yang lebih dekat (banyak) manfaatnya bagimu. ini adalah ketetapan dari Allah. Sesungguhnya Allah Maha mengetahui lagi Maha Bijaksana.(Q.S An-Nisa' ayat: 11)

Hukum waris merupakan suatu aturan yang sangat penting dalam mengurangi ketidakadilan distribusi kekayaan. Hukum waris merupakan alat penimbang yang sangat kuat dan efektif untuk mencegah pengumpulan kekayaan dikalangan tertentu dan pengembangannya dalam kelompok-kelompok besar dalam masyarakat. Tokoh-tokoh ekonomi seperti Keynes,Taussig dan irfing fisher menyetujui bahwa pembagian warisan yang tidak merata merupakan penyebab utama dari ketidak adilan masyarakat. Menurut Taussig,warisan mempunyai dampak yang sangat besar dalm masyarakat.

Menurut hukum waris Islam, harta milik orang lain yang telah meninggal dibagi pada keluarga terdekat, yaitu anak lakilaki/perempuan,saudara,ibu/bapak,suami/istri dan lain-lain. Jika seseorang tidak mempunyai keluarga dekat sama sekali,maka harta bendanya diambil alih oleh Negara. Dengan demikian waris bertujuan untuk menyebarkanluaskan pembagian kekayaan dan mencegah penimbunan harta dalam bentuk apapun.

\section{c. Larangan Penimbunan}

Di dalam Islam melarang penimbunan atau hal-hal yang menghambat pendistribusian barang sampai ke konsumen. Menimbun adalah membeli barang dalam jumlah yang banyak kemudian menyimpannya dengan maksud untuk menjualnya dengan harga tinggi. Penimbunan dilarang dalam Islam hal ini dikarenakan agar supaya harta tidak hanya beredar di kalangan orang-orang tertentu. Seperti dalam sebuah hadits: 


$$
\begin{aligned}
& \text { حدثناسريج حدثنابومعشرعن محمدبن عمروبن علقمةعن ابي سلمة عن ابي هريرة قال:قال رسول }
\end{aligned}
$$

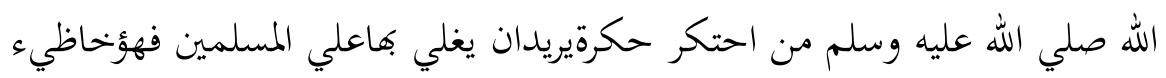

Artinya:" "siapa saja yang melakukan penimbunan untuk mendapatkan harga yang paling tinggi,dengan tujuan mengecoh orang islam maka termasuk perbuatan yang salah"(H.R Ahmad)

Hadits tersebut mengisyaratkan bahwa perbuatan yang salah yaitu menyimpang dari peraturan jual-beli atau perdagangan dalam system ekonomi Islam yang berdasarkan al-quran dan hadits. Dalam hadits itu tidak ditentukan jenis barang yang dilarang ditimbun.Akan tetapi hadits lain yang segaris menyatakan bahwa barang yang dilarang ditimbun adalah makanan. Muncul pebedaan pendapat dikalangan ulama tentang jenis barang yang dilarang ditimbun.

Menurut al-syafi"'iyah dan Hanabilah,barang yang dilarang ditimbun adalah kebutuhan primer.

Abu Yusuf berpendapat bahwa barang yang dilarang ditimbun adalah semua barang yang dapat menyebabkan kemadaratan orang lain,termasuk emas dan perak.

Para ulama fiqh berpendapat bahwa penimbunan diharamkan apabila:

1. Barang yang ditimbun melebihi kebutuhannya

2. Barang yang ditimbun dalam usaha menunggu saat naiknya harga,misalnya emas dan perak

3. Penimbunan dilakukan disaat masyarakat membutuhkan,misalnya bahan bakar minyak dll.

Adapun mengenai waktu penimbunan tidak terbatas,dalam waktu pendek maupun panjang jika dapat menimbulkan dampak ataupun 3 syarat tersebut diatas terpenuhi maka haram hukumnya. Rasullulah bersabda dalam sebuah hadits sohih yaitu:

$$
\begin{aligned}
& \text { حدسنايزيداخبرناصبغ بن زيدحدثنابو بشرعن ابي الزاهريه عن كشير ين مرن الحضرمي عن ابن } \\
& \text { عمر عن النبي صلي الله عليه وسلم من احتكر طعا مااربعين ليله فقدبري من الله تعلي وبريالله }
\end{aligned}
$$

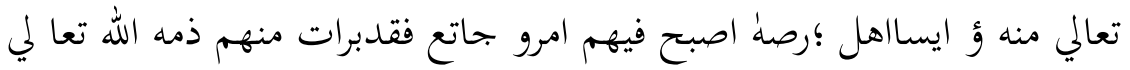

Artinya: Dari ibnu umar dari nabi:"Barang siapa Menimbun makanan 40 malam maka ia terbebas dari rahmad Allah,dan Allah bebas darinya.Barang siapa yang keluar rumah pagi-pagi dan dari kalangan mereka ada yang dalam keadaan lapar maka tanggungan Allah juga lepas dari mereka". 
Pada dasarnya nabi melarang menimbun barang pangan selama 40 hari,biasanya pasar akan mengalami fluktuasi jika sampai 40 hari barang tidak ada dipasar karena ditimbun, padahal masyarakat sangat membutuhkannya. Bila penimbunan dilakukan beberapa hari saja sebagai proses pendistribusian barang dari produsen ke konsumen,maka belum di anggap sebagai sesuatu yang membahayakan. Namun bila bertujuan menungu saatnya naik harga sekalipun hanya satu hari maka termasuk penimbunan yang membahayakan dan tentu saja diharamkan.

\section{Konsumsi dalam Ekonomi Islam}

Menurut Samuelson konsumsi adalah kegiatan menghabiskan utility(nilai guna) barang dan jasa. Barang meliputi barang tahan lama dan barang tidak tahan lama. Barang konsumsi menurut kebutuhannya yaitu : kebutuhan primer, kebutuhan sekunder, dan kebutuhan tertier. ${ }^{28}$

Sifat barang konsumsi menurut Al Ghazali dan Al Shatibi dalam Islam adalah At-Tayyibat. Prinsip konsumsi dalam Islam adalah prinsip keadilan, kebersihan, kesederhanaan, kemurahan hati, dan moralitas. Monzer $\mathrm{Kahf}^{29}$ mengembangkan pemikiran tentang Teori Konsumsi Islam dengan membuat asumsi : Islam dilaksanakan oleh masyarakat, zakat hukumnya wajib, tidak ada riba, mudharabah wujud dalam perekonomian, dan pelaku ekonomi mempunyai perilaku memaksimalkan. Konsep Islam yang dijelaskan oleh Hadits Rasulullah SAW yang maknanya adalah, "Yang kamu miliki adalah apa yang telah kamu makan dan apa yang kamu infakkan."

Terdapat empat prinsip utama dalam sistem ekonomi Islam yang diisyaratkan dalam al Qur'an:

1. Hidup hemat dan tidak bermewah-mewah, yang bermakna bahwa, tindakan ekonomi diperuntukan hanya sekedar pemenuhan kebutuhan hidup(needs) bukan pemuasan keinginan (wants).

2. Implementasi zakat dan mekanismenya pada tataran negara. Selain zakat terdapat pula instrumen sejenis yang bersifat sukarela (voluntary) yaitu infak, shadaqah, wakaf, dan hadiah.

3. Penghapusan Riba; menjadikan system bagi hasil (profit-loss sharing) dengan instrumen mudharabah dan musyarakah sebagai pengganti sistem kredit (credit system) termasuk bunga (interest rate).

4. Menjalankan usaha-usaha yang halal, jauh dari maisir dan gharar; meliputi bahan baku, proses produksi, manajemen, out put produksi hingga proses distribusi dan konsumsi harus dalam kerangka halal.

Dari empat prinsip demikian, terlihat model perilaku muslim dalam menyikapi harta. Harta bukanlah tujuan, ia hanya sekedar alat untuk menumpuk pahala demi tercapainya falah (kebahagiaan dunia dan akhirat). Harta merupakan pokok kehidupan (an-Nisa(4) :5) ${ }^{30}$ yang merupakan karunia Allah (an-Nisa(4) :32 ${ }^{31}$ Islam memandang segala yang ada di di atas bumi dan seisinya adalah milik Allah SWT, 
sehingga apa yang dimiliki manusia hanyalah amanah. Dengan nilai amanah itulah manusia dituntut untuk menyikapi harta benda untuk mendapatkannya dengan cara yang benar, proses yang benar dan pengelolaan dan pengembangan yang benar pula.

Namun pada tingkatan praktis, prilaku ekonomi (economic behavior) sangat ditentukan oleh tingkat keyakinan atau keimanan seseorang atau sekelompok orang yang kemudian membentuk kecenderungan prilaku konsumsi dan produksi di pasar. Dengan demikian dapat disimpulkan tiga karakteristik perilaku ekonomi dengan menggunakan tingkat keimanan sebagai asumsi.

1. Ketika keimanan ada pada tingkat yang cukup baik, maka motif berkonsumsi atau berproduksi akan didominasi oleh tiga motif utama tadi; mashlahah, kebutuhan dan kewajiban.

2. Ketika keimanan ada pada tingkat yang kurang baik, maka motifnya tidak didominasi hanya oleh tiga hal tadi tapi juga kemudian akan dipengaruhi secara signifikan oleh ego, rasionalisme (materialisme) dan keinginan-keinganan yang bersifat individualistis.

3. Ketika keimanan ada pada tingkat yang buruk, maka motif berekonomi tentu saja akan didominasi oleh nilai-nilai individualistis (selfishness); ego, keinginan dan rasionalisme.

Demikian pula dalam konsumsi, Islam memposisikan sebagai bagian dari aktifitas ekonomi yang bertujuan mengumpulkan pahala menuju falah (kebahagiaan dunia dan akherat). Motif berkonsumsi dalam Islam pada dasarnya adalah mashlahah ${ }^{32}$ atas kebutuhan dan kewajiban.

Sementara itu Yusuf Qardhawi ${ }^{33}$ menyebutkan beberapa variabel moral dalam berkonsumsi, di antaranya; konsumsi atas alasan dan pada barang-barang yang baik (halal), berhemat, tidak bermewah-mewah, menjauhi hutang, menjauhi kebakhilan dan kekikiran. Dengan demikian aktifitas konsumsi merupakan salah satu aktifitas ekonomi manusia yang bertujuan untuk meningkatkan ibadah dan keimanan kepada Allah SWT dalam rangka mendapatkan kemenangan, kedamaian dan kesejahteraan akherat (falah), baik dengan membelanjakan uang atau pendapatannya untuk keperluan dirinya maupun untuk amal shaleh bagi sesamanya.

\section{Al Qur'an Sebagai Landasan Aktifitas Konsumsi}

Dalam al-Qur'an ajaran tentang konsumsi dapat diambil dari kata kulu dan isyrabu terdapat sebanyak 21 kali. Sedangkan makan dan minumlah (kulu wasyrabu) sebanyak enam kali. Jumlah ayat mengenai ajaran konsumsi, belum termasuk derivasi dari akar kataakala dan syaraba selain fi'il amar di atas sejumlah 27 kali.

Diantara ayat-ayat konsumsi dalam al-Qur'an adalah Albaqarah(2): 168, 172, 187, al-Maidah(5): 4, 88, al-An'am(6) 118, 141, 142, al-A'raf(7):31, 160, 161, alAnfal(8): 69, an Nahl (16): 114, al-Isra(17): 26-28, Toha(20): 54, 81, al-Hajj(22): 28, 
36, al-Mukminun(23): 51, $\operatorname{Saba(34):~15,~at-Tur(52):~19,~al-Mulk~(67):~15,~al-~}$ Haqqah(69): 24, almursalat(77): 43, 46 dan lain-lain. 
Dalam tulisan ini hanya akan difokuskan pada ayat-ayat berikut:

Al-Baqarah(2): Ayat 168,

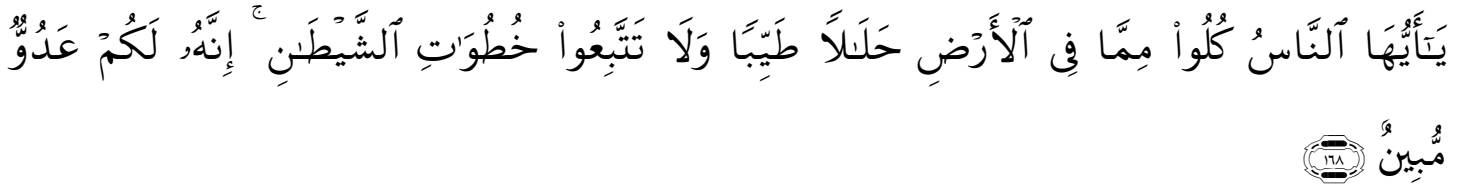

Hai sekalian manusia, makanlah yang halal lagi baik dari apa yang terdapat di bumi, dan janganlah kamu mengikuti langkah-langkah syaitan; Karena Sesungguhnya syaitan itu adalah musuh yang nyata bagimu.

\section{An-Nahl (16): ayat 114}

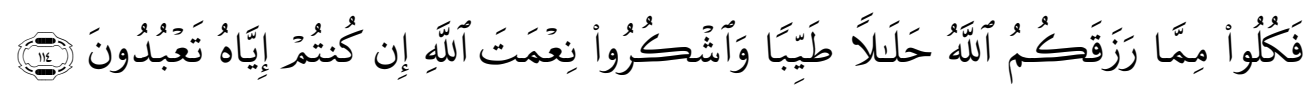

Maka makanlah yang halal lagi baik dari rezki yang Telah diberikan Allah kepadamu; dan syukurilah nikmat Allah, jika kamu Hanya kepada-Nya saja menyembah.

Pada kedua ayat secara tegas, terdapat prinsip halal dan baik, prinsip ketiadaan mengikuti hawa nafsu, prinsip syukur dan prinsip tauhid. Dengan prinsip-prinsip demikian, maka pola konsumsi seseorang dan juga masyarakat, diarahkan kepada kebutuhan dan kewajiban berdasakan standar-standar prinsip di atas. Demikian pula, dalam ayat-ayat berikut;

\section{Al-Isra (17): ayat 26-28,}

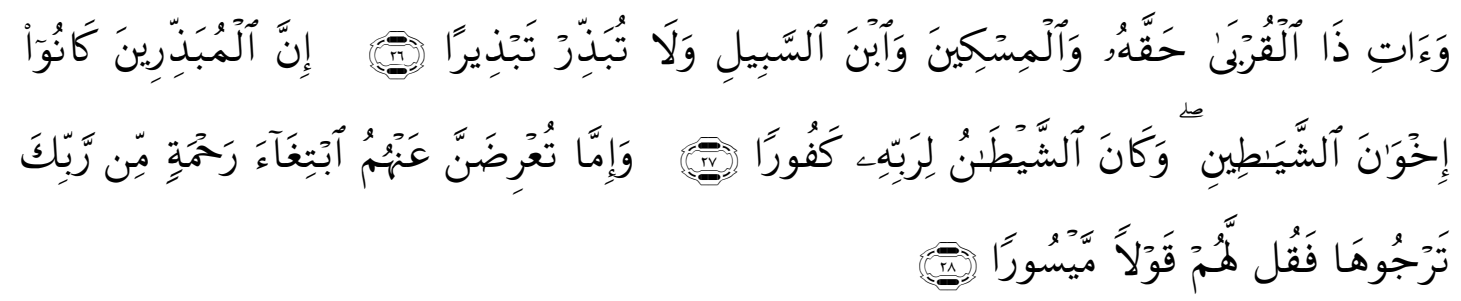

26. Dan berikanlah kepada keluarga-keluarga yang dekat akan haknya, kepada orang miskin dan orang yang dalam perjalanan dan janganlah kamu menghamburhamburkan (hartamu) secara boros.

27. Sesungguhnya pemboros-pemboros itu adalah Saudara-saudara syaitan dan syaitan itu adalah sangat ingkar kepada Tuhannya.

28. Dan jika kamu berpaling dari mereka untuk memperoleh rahmat dari Tuhanmu yang kamu harapkan, Maka Katakanlah kepada mereka Ucapan yang pantas. 
Al-A'raf (7) : ayat 31-32

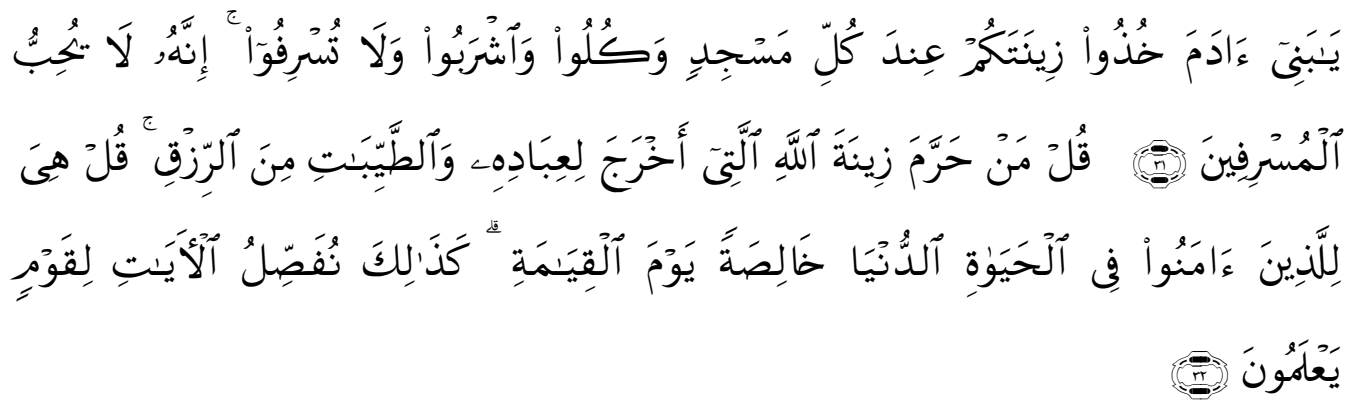

31. Hai anak Adam, pakailah pakaianmu yang indah di setiap (memasuki) mesjid, makan dan minumlah, dan janganlah berlebih-lebihan[535]. Sesungguhnya Allah tidak menyukai orang-orang yang berlebih-lebihan.

32. Katakanlah: "Siapakah yang mengharamkan perhiasan dari Allah yang Telah dikeluarkan-Nya untuk hamba-hamba-Nya dan (siapa pulakah yang mengharamkan) rezki yang baik?" Katakanlah: "Semuanya itu (disediakan) bagi orang-orang yang beriman dalam kehidupan dunia, khusus (untuk mereka saja) di hari kiamat." Demikianlah kami menjelaskan ayat-ayat itu bagi orang-orang yang Mengetahui.

Pada kedua ayat di atas, terdapat prinsip menjauhkan diri dari kekikiran baik pada diri sendiri maupun terhadap orang lain. Demikian pula terdapat prinsip proporsionalitas dalam melakukan aktivitas konsumsi. Dan prinsip pertanggung jawaban dalam setiap aktivitas konsumsi.

Hal ini berdasar pada ayat al-Mulk(67): 15.

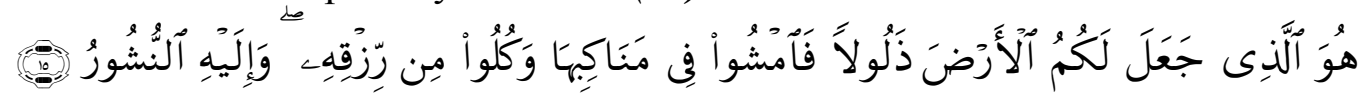

15. Dialah yang menjadikan bumi itu mudah bagi kamu, Maka berjalanlah di segala penjurunya dan makanlah sebahagian dari rezki-Nya. dan Hanya kepada-Nya-lah kamu (kembali setelah) dibangkitkan.

Lukman (31) : Ayat 20

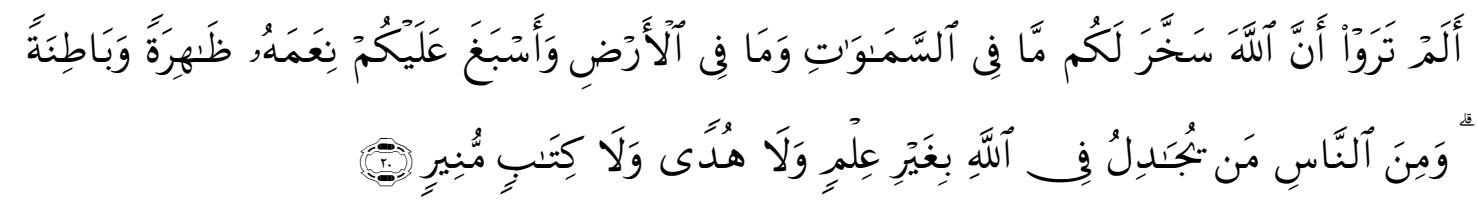

20. “Tidakkah kamu perhatikan sesungguhnya Allah telah menundukkan untuk (kepentingan)mu apa yang di langit dan apa yang di bumi dan menyempurnakan untukmu nikmat-Nya lahir dan bathin." 
Apa yang diungkapkan Hasan Al Banna, menegaskan bahwa ruang lingkup keilmuan ekonomi Islam lebih luas dibandingkan dengan ekonomi konvensional. Ekonomi Islam bukan hanya berbicara tentang pemuasan materi yang bersifat fisik, tapi juga berbicara cukup luas tentang pemuasan materi yang bersifat abstrak, pemuasan yang lebih berkaitan dengan posisi manusia sebagai hamba Allah SWT.

\section{Kesimpulan}

Dalam tulisan ini, sekiranya dapat diambil pelajaran bahwa setelah kita sebagai pelaku ekonomi mengoptimalkan seluruh sumber daya yang ada di sekitar kita (dalam ayat-ayat yang diterangkan dalam isi tulisan; binatang ternak, pegunungan; tanah perkebunan, lautan dengan kekayaannya, ingat lagi pandangan al-Qur'an tentang harta benda yang disebut sebagai Fadlum minallah)sebagai media untuk kehidupan di dunia ini, lalu kita diarahkan untuk melakukan kebaikan-kebaikan kepada saudara kita, kaum miskin, kaum kerabat dengan cara yang baik tanpa kikir dan boros.

Dalam konteks produksi, tentu saja produsen muslim sama sekali sebaiknya tidak tergoda oleh kebiasaan dan perilaku ekonom-ekonom yang bersifat menjalankan dosa, memakan harta terlarang, menyebarkan permusuhan, berlawanan dengan sunnatullah, dan menimbulkan kerusakan di muka bumi. Walau bagaimanapun, secanggih alat untuk menghitung nikmat Allah pasti tidak akan menghitungnya.

Di lain pihak, dalam faktor lainnya yaitu konsumsi, tentunya ini berkaitan dengan penggunaan harta. Hal ini dikarenakan, bahwasanya harta merupakan pokok kehidupan (an-Nisa(4) :5) yang merupakan karunia Allah (an-Nisa(4) :32. Islam memandang segala yang ada di di atas bumi dan seisinya adalah milik Allah SWT, sehingga apa yang dimiliki manusia hanyalah amanah.

Dalam konseptual konsumsi yang tercermin dari ayat-ayat yang ditampilkan dalam isi tulisan ini, ada beberapa prinsip yang harus dipatuhi oleh konsumen muslim.

Dengan prinsip-prinsip demikian, maka pola konsumsi seseorang dan juga masyarakat, diarahkan kepada kebutuhan dan kewajiban yang sepadan dengan pola kehidupan yang sesederhana mungkin.

Sebenarnya, dalam ekonomi Islam paremeter kepuasan bukan hanya terbatas pada benda-benda konkrit (materi), tapi juga tergantung pada sesuatu yang bersifat abstrak, seperti amal shaleh yang manusia perbuat. Kepuasan dapat timbul dan dirasakan oleh seorang manusia muslim ketika harapan mendapat kredit poin dari Allah SWT melalui amal shalehnya semakin besar 


\section{Catatan Akhir:}

${ }^{1}$ M.M. Metwally, "A Behavioural Model of An Islamic Firm," Readings in Microeconomics: An Islamic Perspektif, Longman Malaysia (1992), hlm. 131-138.

${ }^{2}$ M.A. Mannan, "The Behaviour of The Firm and Its Objective in an Islamic Framework", Readings in Microeconomics: An Islamic Perspektif, Longman Malaysia (1992), hlm. 120-130.

${ }^{3}$ Muhammad Abdul Mun'im 'Afar dan Muhammad bin Sa'id bin Naji Al-Ghamidi, Ushul Al-Iqtishad Al-Islami, hlm. 59-60.

${ }^{4}$ Yusuf Qardhawi, Norma dan Etika Ekonomi Islam, Jakarta: Gema Insani Press. 1997. hlm. 117-118.

${ }^{5}$ Larangan membunuh diri sendiri mencakup juga larangan membunuh orang lain, sebab membunuh orang lain berarti membunuh diri sendiri, karena umat merupakan suatu kesatuan.

${ }^{6}$ Afzalur Rahman, Doktrin Ekonomi Islam, Jld 1. Yogyakarta: Dana Bhakti Wakaf. 1995. hlm. 215 217.

${ }^{7}$ A. Rahman I. Doi, Penjelasan Lengkap Hukum-Hukum Allah (Syariah) Jakarta: PT Raja Grafindo Persada, 2002, hlm. 188-189.

8 Hendrie Anto, Pengantar Ekonomika Mikro Islami, (Yogyakarta : Jalasutra), 2003, hal. 156

9 Ibid., hal. 157-158

${ }^{10}$ Lihat misalnya pada Al-Qur'an Surat Ibrahim 32-34 :32.Allah-lah yang Telah menciptakan langit dan bumi dan menurunkan air hujan dari langit, Kemudian dia mengeluarkan dengan air hujan itu berbagai buah-buahan menjadi rezki untukmu; dan dia Telah menundukkan bahtera bagimu supaya bahtera itu, berlayar di lautan dengan kehendak-Nya, dan dia Telah menundukkan (pula) bagimu sungai-sungai.33. Dan dia Telah menundukkan (pula) bagimu matahari dan bulan yang terus menerus beredar (dalam orbitnya); dan Telah menundukkan bagimu malam dan siang. 34. Dan dia Telah memberikan kepadamu (keperluanmu) dan segala apa yang kamu mohonkan kepadanya. dan jika kamu menghitung nikmat Allah, tidaklah dapat kamu menghinggakannya. Sesungguhnya manusia itu, sangat zalim dan sangat mengingkari (nikmat Allah).

11 Ayat yang berkaitan dengan faktor produksi Tenaga Kerja dalam Surat Huud : 61 (Dan kepada Tsamud (Kami utus) saudara mereka shaleh. Shaleh berkata: "Hai kaumku, sembahlah Allah, sekalikali tidak ada bagimu Tuhan selain Dia. dia Telah menciptakan kamu dari bumi (tanah) dan menjadikan kamu pemakmurnya, Karena itu mohonlah ampunan-Nya, Kemudian bertobatlah kepadaNya, Sesungguhnya Tuhanku amat dekat (rahmat-Nya) lagi memperkenankan (doa hamba-Nya)."

Kata kunci dari faktor produksi tenaga kerja terdapat dalam kata wasta'marakum yang berarti pemakmur. Manusia sebagai khalifah dimuka bumi ini diharapkan oleh Allah untuk menjadi pemakmur bumi dalam pemanfaatan tanah dan alam yang ada. Kata pemakmur mengindikasikan untuk selalu menajdikan alam ini makmur dan tidak menjadi penghabis (aakiliin) atau perusak alam (faasidiin). Manusia dengan akalnya yang sempurna telah diperintahkan oleh Allah untuk dpaat terus mengoleh alam ini bagi kesinambungan alam itu sendiri, dalam hal ini nampaklah segala macam kegiatan produksi amat bergantung kepada siapa yang memproduksi (subyek) yang diharapkan dpat menjadi pengolah alam ini menuju kepada kebahagiaan dunia dan akhirat. Ayat yang berkaitan dengan faktor produksi Modal dalam Surat Al-Baqarah : 272 Bukanlah kewajibanmu menjadikan mereka mendapat petunjuk, akan tetapi Allah-lah yang memberi petunjuk (memberi taufiq) siapa yang dikehendaki-Nya. dan apa saja harta yang baik yang kamu nafkahkan (di jalan Allah), Maka pahalanya itu untuk kamu sendiri. dan janganlah kamu membelanjakan sesuatu melainkan Karena mencari keridhaan Allah. dan apa saja harta yang baik yang kamu nafkahkan, niscaya kamu akan diberi pahalanya dengan cukup sedang kamu sedikitpun tidak akan dianiaya (dirugikan).

Modal sangat penting dalam kegiatan produksi baik yang bersifat tangible asset maupun intangible asset. Kata apa saja harta yang baik menunjukkan bahwa manusia diberi modal yang cukup oleh Allah untuk dapat melakukan kegiatan pemenuhan kebutuhannya secara materi. Modal dapat pula memberikan makna segala sesuatu yang digunakan dan tidak habis, untuk diputarkan secara ekonomi dengan harapan dari modal tersebut menghasilkan hasil yang lebih, dari hasil yang lebih tersebut terus 
diputar sampai pada pencapaian keuntungan yang maksimal (profit) dari modal yang kita miliki yang pada akhirnya tercapailah suatu optimalisasi dari modal tersebut.

${ }^{12}$ Suherman Rosyidi, Pengantar Teori Ekonomi Pendekatan kepada Teori Ekonomi Mikro dan Makro, Jakarta: PT Raja Grafindo Persada, 2006, hlm. 55.

${ }^{13}$ Masyhuri, Ekonomi Mikro, Malang: UIN Malang Press. 2007. hlm. 125.

${ }^{14}$ M. Mutawalli Sya'rawi, Islam di Antara Kapitalisme dan Sosialisme, Jakarta: Gema Insani Press, 1996. Hlm. 13.

${ }^{15}$ Monzer Kahfi. Ekonom Islam; Telaah Analitik terhadap Fungsi Sistem Ekonomi Islam, Yogyakarta: Pustaka Pelajar, 1997. Hlm 45

16 Mustafa Husin al-Siba'i, Kehidupan Sosial menurut Islam Tuntutan Hidup Bermasyaraka,. Bandung: Diponegoro.1996. hlm 160

${ }^{17}$ Muhammad Abdul Mun'im Afr, Al-Syiasah al- Iqtisadiyah fi al-Itari Maqasid al Syri'ayah alIslamiya, Mekah: Umm al-Qur'an. hlm 18.

${ }^{18}$ A. A. Islahi, Konsep Ekonomi Ibnu Taymiyah, Surabaya: Bina Ilmu. 2002. Hlm. 145.

${ }^{19}$ Muhammad Abdul Mun'in Afr, op.cit., hlm. 318.

${ }^{20}$ Mustafa Edwin Nasution, et. al, Pengenalan Eksklusif Ekonomi Islam, Kencana, Jakarta, 2010, hal. 119

${ }^{21} \mathrm{Ibid}$

${ }^{22}$ Al Masry, Rafeq Younes, Ushûl Al Iqtishâd Al Islâmy, (Beirut: Al Daar As Syaamiyah, 1999), h. 226.

${ }^{23}$ Qal'aji, mabahist fi al-Iqtishad al-Islamy min Ushulihi al Fiqhiyyah, (Beirut: Dar an Nafaes, 2000), h. 87

${ }^{24}$ HR. Muslim pada Pembahasan Kebaikan dan Silaturrahmi, Bab Anjuran untuk Memaafkan.

${ }^{25} \mathrm{Qal}$ 'aji, Mabâhist fi al Iqtishâd al Islâmy min Ushûlihî al Fiqhiyyah, (Beirut: Dar an Nafaes, 2000), h. 87; Al Jazri, Mubarak Ibnu al Atsir, Jâmi al Ushûl, no. 3645 (Kuwait: Maktbah al Mallah, 1392)

${ }^{26}$ Qal'aji, Mabâhist fi al Iqtishâd al Islâmy min Ushûlihî al Fiqhiyyah, (Beirut: Dar an Nafaes, 2000), h. 87

${ }^{27}$ Lebih lanjut lihat, Qal'aji, Mabâhist fi al Iqtishâd al Islâmy min Ushûlihî al Fiqhiyyah, (Beirut: Dar an Nafaes, 2000), h. 88.

${ }^{28}$ Samuelson., Paul, Nordhaus., William D, 2000, Macroeconomics, John Willey \& Sons, New York

${ }^{29}$ Kahf., Monzer, 1984, The Islamic Economy : An Analytical Study of the Functioning of the Islamic

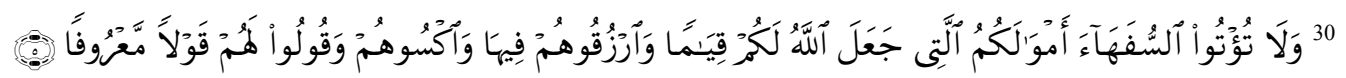

dan janganlah kamu serahkan kepada orang-orang yang belum sempurna akalnya[268], harta (mereka yang ada dalam kekuasaanmu) yang dijadikan Allah sebagai pokok kehidupan. berilah mereka belanja dan pakaian (dari hasil harta itu) dan ucapkanlah kepada mereka kata-kata yang baik.

[268] Orang yang belum sempurna akalnya ialah anak yatim yang belum balig atau orang dewasa yang tidak dapat mengatur harta bendanya.

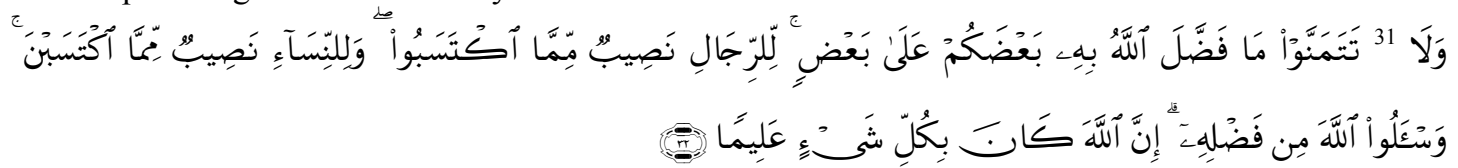

dan janganlah kamu iri hati terhadap apa yang dikaruniakan Allah kepada sebahagian kamu lebih banyak dari sebahagian yang lain. (karena) bagi orang laki-laki ada bahagian dari pada apa yang mereka usahakan, dan bagi Para wanita (pun) ada bahagian dari apa yang mereka usahakan, dan mohonlah kepada Allah sebagian dari karunia-Nya. Sesungguhnya Allah Maha mengetahui segala sesuatu. 
32 Mashlahah secara bahasa berarti kebergunaan (utility) atau kesejahteraan (welfare), yang oleh Abu Hamid Al Ghazali (505 H/1111 M) dan Abu Ishaq Al Shatibi (790 H/1388 M) masalih (plural of Mashlahah) dibagi menjadi tiga kategori; esensial (essential/daruriyah), pelengkap (complementary/hajiyah) dan keinginan (desirable/tahsiniyah). Dan tugas negaralah yang memastikan kemashlahatan kategori pertama dari masyarakat itu terpenuhi dengan baik. Lihat Muhammad Akram Khan, "The Role of Government in the Economy," The American Journal of Islamic Social Sciences, Vol. 14, No. 2, 1997, p. 157.

33 Yusuf Qardhawi, "Peran Nilai dan Moral dalam Perekonomian Islam," Rabbani Press, Jakarta (1995).

\section{DAFTAR PUSTAKA}

A. A. Islahi, Konsep Ekonomi Ibnu Taymiyah, Surabaya: Bina Ilmu, 2002.

Afzalur Rahman, Doktrin Ekonomi Islam, Jld 1. Yogyakarta: Dana Bhakti Wakaf. 1995.

Al Jazri, Mubarak Ibnu al Atsir, Jâmi al Ushûl, no. 3645 (Kuwait: Maktbah al Mallah, 1392.

Al Masry, Rafeq Younes, Ushûl Al Iqtishâd Al Islâmy, Beirut: Al Daar As Syaamiyah, 1999

Hendrie Anto, Pengantar Ekonomika Mikro Islami, (Yogyakarta : Jalasutra), 2003

Kahf., Monzer, The Islamic Economy : An Analytical Study of the Functioning of the Islamic, 1984

M. Mutawalli Sya'rawi, Islam di Antara Kapitalisme dan Sosialisme, Jakarta: Gema Insani Press, 1996

M.A. Mannan, "The Behaviour of The Firm and Its Objective in an Islamic Framework", Readings in Microeconomics: An Islamic Perspektif, Longman Malaysia 1992

M.M. Metwally, “A Behavioural Model of An Islamic Firm," Readings in Microeconomics: An Islamic Perspektif, Longman Malaysia 1992

Masyhuri, Ekonomi Mikro, Malang: UIN Malang Press. 2007. 
Monzer Kahfi. Ekonom Islam; Telaah Analitik terhadap Fungsi Sistem Ekonomi Islam, Yogyakarta: Pustaka Pelajar, 1997.

Muhammad Abdul Mun'im 'Afar dan Muhammad bin Sa'id bin Naji Al-Ghamidi, Ushul Al-Iqtishad Al-Islami, tp.t.th

Muhammad Abdul Mun'im Afr, Al-Syiasah al-Iqtisadiyah fi al-Itari Maqasid al Syri'ayah al- Islamiya, Mekah: Umm al-Qur'an, t,th

Mustafa Edwin Nasution, et. al, Pengenalan Eksklusif Ekonomi Islam, Kencana, Jakarta, 2010

Mustafa Husin al-Siba'i, Kehidupan Sosial menurut Islam Tuntutan Hidup Bermasyaraka,. Bandung: Diponegoro.1996.

Qal'aji, mabahist fi al-Iqtishad al-Islamy min Ushulihi al Fiqhiyyah, (Beirut: Dar an Nafaes, 2000

Rahman I. Doi, Penjelasan Lengkap Hukum-Hukum Allah (Syariah) Jakarta: PT Raja Grafindo Persada, 2002

Samuelson., Paul, Nordhaus., William D, Macroeconomics, John Willey \& Sons, New York, 2000

Suherman Rosyidi, Pengantar Teori Ekonomi Pendekatan kepada Teori Ekonomi Mikro dan Makro, Jakarta: PT Raja Grafindo Persada, 2006

Yusuf Qardhawi, Norma dan Etika Ekonomi Islam, Jakarta: Gema Insani Press, 1997

Widya Sari, dosen IAIN Raden Intan Lampung 